\title{
9 The Archaeology of Urbanization: Research Design and the Excavation of an Archaic Greek City on Crete
}

\begin{abstract}
Archaeological evidence is accumulating rapidly, providing us with immensely valuable information about changes in population density, settlement distribution and structure, subsistence and trade, social differentiation, and much more... But the rise of the polis entails more than this: it is the history of a relationship between peoples and their communities. To understand this, we need the help of written sources (Raaflaub 1993, 43).
\end{abstract}

Historical particularism beckons like the girl next door and offers about as much. For archaeologists, history too often means referencing the same set of secondary sources (in English), leaning up against the old barn of the historical approach, or drawing historical analogies so grand they are untestable or so small they would be nothing at all for Mickey Mouse (Kowalewski 2006, 94).

\begin{abstract}
The paper examines culture change on Crete, ca. 600 B.C., in an urban context. The purpose is to reassess the current methodological discourse, and the application of site-specific recovery methods and research paradigms in addressing traditional problems of polis formation and urbanization in the Greek Aegean. One aspect of urbanization in the Aegean at the end of the Early Iron Age is nucleation of population, the settlement aggregation and the restructuring of social, political and economic landscapes, giving rise to Archaic Greek cities and city-states. This paper presents a case study of an excavation of one such early emergent center, the site of Azoria in eastern Crete (700-500 B.C.). Within contexts of agropastoral production and consumption in domestic and communal spaces, the material patterns suggest public activities that actively formed civic institutions, mediating social and political interaction and forming mechanisms of community organization and integration.
\end{abstract}

\section{The Problem with the Archaeology of Archaic Urbanization}

In studies of the emergence and form of ancient Greek cities there has been a decided shift in analytical focus from the urban center to its hinterland, probably as a result of the scaling back of large-scale excavation, as well as the growth of intensive archaeological survey in the Aegean since the 1980s. The question of the physical form of the city through time-as an aggregated center or nucleated settlement (Hansen 1997, 9, 54-57)-has become in many respects moot. The Archaic city is too difficult to expose stratigraphically or spatially; in its earliest stages, it was formally and functionally inconsistent, or spatially incoherent; and for the most part, its formal attributes, even if recoverable, are considered irrelevant to understanding social and political questions of the emergence of state-level societies in the classical Aegean. On another 
level, early civic architecture, sensu stricto as buildings for ascribed magistracies, is hard to define materially except in general terms of vaguely communal or public venues of social and economic interaction (Hansen 1997, 15-17), and with few exceptions, the specific forms or types of monumental political architecture seems hard to pin down until the late fifth and fourth centuries B.C. (Hansen 1997, 55). A related aspect of the question of urbanism is of course its relationship to actual social and political structure. The physical form of urban centers and their development through time may be methodologically irrelevant to serious discussion of the conceptualization of the polis, while any consideration of diachronic change invites necessarily gradualist and macroscalar perspectives of both city (Osborne 2005; Wallace 2010a; 2010b) and state (Morris 1991).

Thus, the distinction between the city as a materially comprehensible condition in the archaeological record of the fifth and fourth centuries, and urbanization as a long-term cultural dynamic of the Early Iron Age (EIA) and early Archaic periods, culminating in the sixth century, brings with it a number of problems. Foremost among these is the difficulty in finding, interpreting, and identifying phases of a process in a number of specific and contiguous stratigraphic contexts; and then defining the physical attributes of the city itself, which are nevertheless chronologically, geographically, and culturally variable. Finally, our attempts at understanding the development and physical forms of cities may be incidental, if not also ultimately tangential to understanding the social and political dynamics of city-state formation.

Given our frustration with (or benign neglect of) the study of the archaeology of the early Greek city, it follows that current approaches should privilege material correlates recoverable within broad diachronic and regional scales of analysis, precisely because we have assumed a continuum of development and a diversity of forms and structures (such as buildings and fortifications), as well as types of political organization (e.g., Osborne 2005; Morgan and Coulton 1997). The strictly materialist approach, normally eschewed in recent critical analyses, derives of course in large part from the categorical definition of formal and systemic attributes most appropriate to already fully developed Greek cities of the Classical period, such as settlement size and population density; cultic, civic, domestic or political architecture; articulation and separation of cultic, political, and habitation spaces; extramural cemeteries; economic structure; and inscriptions; and of course the location and relative scale of these various attributes. The potential usefulness of these indices has been weakened in recent studies of Greek urbanization for good reason. Polignac, for example, has argued that any analysis of urbanization as a process, necessarily requires evaluation of evidence of the eighth and seventh centuries (2005, 46, 52-53), amounting to a retrojection of criteria derived from much later contexts-a kind of ideal or notional city-in order to identify individual developing forms or conceptual degrees of urbanism in the Early Iron Age and early Archaic records (Preston and Owen, eds., 2009, 3-4; Osborne 2005, 7; Morgan and Coulton 1997, 129; Morris 1991, 39-40). The 
problem with this material retrojection of course is that urbanization is a dynamic cultural process with complex and diverse systemic correlates (cf. Raaflaub 1993, 43). Even if we generally acknowledged a sixth-century terminus ante quem for the materialization of the city itself, we link its material form to certain kinds of social and political behaviors, and so perceive it as a continuous and long-term development that is, simply put, hard to pin down materially or stratigraphically. The end result is a kind of arbitrary interpretation of Early Iron Age and early Archaic contexts, singling out and defining certain features and installations that should reflect aspects of notional or "Classical" city-like behavior.

This is the critique of the materialist perspective. Even if we accept uncritically a teleological vision (early versions or formative permutations) of the city, insisting on a number of particular components, the actual definition of those formative elements is seen as simply too varied, arbitrary, reductive, stratigraphically narrow, and spatially inconsistent in any period to provide us anything but the most general conceptual framework (Polignac 2005; Osborne 2005, 13; Morgan and Coulton 1997, 120, 128-129). Also, even though we might recognize the evidence of certain urban features as late as the seventh or sixth centuries (Osborne 2005, 7-10; Polignac 2005, 46; Morgan and Coulton 1997, 121; Morris 1991, 40), the definition of their functions in archaeological contexts, even if plausible or compelling, in and of themselves, does little to explain regionally and chronologically variable settlement systems and structures that constitute the political or cultural landscape (Morgan and Coulton 1997, 121)-the spatially- and temporally-specific patterns that reflect fluid and dynamic sociopolitical configurations and processes (Preston and Owen, eds., 2009, 3; Polignac 2005, 46, 54).

A consequence of this condition of the archaeological record (and our normative developmental paradigms) is that the study of Greek cities has become mired in the limitations of the archaeological record itself, a product and a condition of our own creation, research designs, and decisions in the field; a result of our self-defined research universe, the limitations of our own metanarratives, and our justifiable privileging of epigraphical and literary sources. Even where archaeology does not fail us altogether, we insist on identifying spaces, buildings and contexts for civic institutions derived from written sources that are not always coterminous with, or even relevant to, the archaeological contexts in question. In spite of our historical bent, I think it is important to recognize that the problems we have in defining the Archaic city may also be less methodological than material. That is, we lack archaeological evidence and stratigraphic clarity in the Archaic city itself. Urban features and even definable physical contexts for civic institutions are neither geographically nor chronologically consistent (nor particularly well excavated or studied); and archaeological contexts can only provide single instances of certain forms of human behavior in certain periods. There is also of course the added problem that we still do not conceive of the early Greek city as being materially remarkable. The small scale of most poleis, even well into the Classical period, show few characteristics of large-scale agglomerations 
that we associate with urbanization elsewhere in the Mediterranean, and in later Hellenistic and Roman periods (e.g., Bintliff 2012, 217).

We do, however, generally understand what Greek cities looked like because of the big colonialist-style digs of the past century that encouraged the broad horizontal scale of extensive excavation that we need. But I would argue that our research questions have now perhaps outpaced the quality or usefulness of the data produced by the research strategies and excavation methods of these early projects. So while Emanuele Greco is right to point out the irony of the situation, that "if today we can answer certain questions with just a few well-aimed soundings, we owe this to the much criticized extensive excavations of the past" $(2009,115)$, it is also true that many such questions in fact require first, extensive excavation that is probably no longer financially or practically feasible; and second, properly recovered and documented samples derived from known excavated contexts. Unfortunately many of the latter from older excavations are already long destroyed because of methods, or irrevocably distorted by recording techniques and resultant narratives. Indeed a further irony of the study of the Archaic city is that the increased cost (time, labor allocation, and resources) of extensive excavation is now indirectly related to the development of intensive and problem-oriented sampling strategies, and the increased complexity and study and publication requirements of implementing appropriate and responsible recovery and conservation methods.

This difficulty of actually being able to excavate Greek cities, as well as the entrenchment of traditional discourses based on very limited and distorted data sets, dovetailed nicely with the emergence of intensive and diachronic archaeological survey in the Aegean in the 1970s and 1980s (Osborne 2005, 4). First, survey was a liberating intellectual and practical antidote to the destructive big dig: surveys claimed to ask important archaeological questions that addressed precisely what both new and old excavation narratives seemed to want but could not deliver because of either excavation techniques or narrow sampling: settlement histories and diachronic, environmental, and regional perspectives on cultural and historical landscapes of variable scales. Surveys also boasted that they were non-destructive, and also apparently cheaper and less complicated logistically to implement. While neither of the latter statements is entirely true, it can be said that surveys provided a reorientation of questions that emphasized the relationship between city and countryside in defining the form and function of the city, as both town and economic community. Survey also encouraged an awareness of the effective analytical scales required by our research questions, and the limitations of the existing excavation sample in providing the evidence we need in order to answer questions about the ancient city and its origins. While the efficacy of survey no longer needs to be justified, let alone heralded-it is obvious enough in Osborne and Cunliffe's (2005) and Owen and Preston's (2009) recent collections of papers-we still struggle with urbanization as a material phenomenon on the site-level, as a process distinct from concepts of macroscalar centralization, aggregation, or nucleation (Polignac 2005; Morris 1991, 39-40). 
Emblematic of the shift in orientation by the 1990s is Morgan and Coulton's (1997, 128-129) insistence that since there are no absolute or consistent archaeological criteria for identifying an Archaic site as a polis town, we should instead turn to the region as the effective analytical scale. Emphasizing the polis as a continuum of development (cf. Morris 1991; Hansen 1997; Osborne 2005), their logical conclusion was that it may only be possible to identify a site as a polis town when the city-state itself is already known and located, that is, a site is recognized as a polis in the regional and political sense, and presumably in the historical record. This perspective characterizes the circularity of the problem, and the methodological dead-end in trying to understand, from the standpoint of excavation, the earliest cities as social and political centers. We lack materially consistent definitions of spaces, stratigraphic resolution on synchronic functions or diachronic developments, and meaningful data that we can relate to patterns derived from environmental and archaeological sampling in the region.

Even so, we still commonly accept the formalization of the temple as being an essential aspect of the early materialization of polis identity (Polignac 1995, 31; Hansen 1997, 57; Osborne 2009, 239-241; cf. Wallace 2010b, 282). But we remain rather ambivalent about settlement aggregation, nucleation, and other material forms or installations making up the urban landscape. By saying, as Hansen does $(1997,17)$, that no urban structures clearly delineated civic institutions-in the sense of political architecture used exclusively by a narrowly defined social or political class-he calls attention to the fluid nature of the communal spaces in Greek cities, which were, perhaps before the late Classical period, by and large, roughly formed and variable in function, depending on context and specific activity rather than consistently identifiable types of architecture. As Hansen and Fischer-Hansen (1994, 37) comment on prytaneia, if Steven Miller knew what one actually looked like, as a type of building, he would have illustrated one on the cover of his seminal work, The Prytaneion (Miller 1978). Indeed even more recently, in Crielaard's chapter on Archaic cities in the Blackwell Companion to Archaic Greece (2013, 365-366), the temple and agora seem to be the only features of the early urban center with visible material correlates worth any elaboration at all. This analytical thread, and our apparently ineffective search for certain kinds of public spaces, present the early urban landscape as either all civic, in the sense that it generally belonged to the city as a whole; or largely non-civic, as above, in the sense that it must have lacked definitive or generic types of buildings for exclusive political functionaries. Thus our narrative of what the Archaic city should have looked like tends to steer us away from the potential of the middle range to explain the archaeology of communal space, toward a definition the urban sphere.

My argument here is that the close examination of archaeological context might help us come to a more nuanced definition of civic spaces, and a closer understanding of urbanization and urbanism as products of social interaction and cultural production (see Donati; and Stefanakis et al., this volume). By this I mean two things. 
First, although Archaic civic institutions may not appear to have had consistent material forms, and their activities could have been carried out in a variety of places, we need nevertheless to recognize that the activities themselves may have consistently identifiable archaeological contexts and correlates. While I am not at all convinced that the current state of the archaeological record is sufficiently well formed to say definitively that Archaic civic institutions do not have comparable physical forms or features (or even building types), as it is normally argued, we might at least find comparable material patterns if we look at actual archaeological contexts of the use of spaces and buildings.

This will entail examining multi-temporal landscapes, and looking beyond the building as a synchronic artifact or monument-the architectural plans and reconstructions that have become the basis of orthogenic and reductive formal typologies in classical archaeology. And second, if we look at the architecture itself as a component of the built environment-that is as parts of contexts rather than formally consistent types of historically-attested or functional architecture-examining patterns of structure and scale, labor mobilization, organization of space, communication and accessibility, use and function, and visual or aesthetic physical forms (such as monumentalization, aspect, and visibility), we might come to a conceptual view of urban space that can allow us to begin to model social activities and cultural processes as long-term patterns of activity and modes of behavior. This would entail studying the structuring of contexts, such as how food and other resources were procured, processed, stored, redistributed and consumed; and how spaces for food and craft production, cult, and domestic and communal activities were integrated and constructed on an intra-site level.

Turning our emphasis away from formal typologies of components of civic spaceconsistent political architectural forms that predicate the urban character of a site; or a laundry list of a priori features with installations such as agoras, fortifications, council houses, temples, and communal cemeteries-to the evidence of how these spaces functioned, we might begin to visualize the development of urban spaces as culturally and chronologically meaningful components of urbanization.

I am not saying that particular types or forms of civic or religious or domestic architecture are not materially relevant; only that by assessing their archaeological contexts-evaluating material patterns and modeling the use of space-can we begin to grapple with the diversity of contexts, and in our narratives, bring together very different looking configurations of material culture, which seems to be our biggest stumbling block. Furthermore, in assessing urbanization as a process of change, that is, emerging or developing structures or singular punctuated events, we need vertical stratigraphy; samples that permit evaluation and comparison of data through time, as well as a number of contexts that suggest specific activities, behaviors, and social and economic strategies.

Recent excavations at Azoria, an Archaic site in eastern Crete, present an opportunity to examine evidence for settlement restructuring at the end of the seventh 
century (Haggis et al. 2011a; 2011b). The question I am asking of these data is whether or not it is useful to think of the stratigraphic changes in terms of social processes: the design and formalization of the Archaic settlement as a self-conscious assertion of regional political identity; as the center of a political and economic region with a definable agropastoral resource base; and as a polis town with distinctive systemic contexts that defined the structure of the community (Haggis 2013; 2014a; 2014b). From an archaeological point of view, I admit that the point of physical transformation or materialization of the city should logically represent only the terminus ante quem or end result of a process of change-a peak in a range of developmental cycles, or perhaps one point along a continuum of change. In the current thinking on urbanization and polis formation, this single point should represent a manifestation, or scaling up, of a preexisting community and integrated sociopolitical structure, so therefore largely irrelevant to the concept of city-state formation, which had presumably already taken place. I want to consider challenging, or at least rethinking this perspective.

\section{The Neoevolutionist Viewpoint and Protogeometric-Geometric Crete}

A gradualist view of Cretan patterns, fitting remarkably well with the foregoing critique of Greek urbanization, has been eloquently presented by Saro Wallace (2010a; 2010b), who sees a critical phase transition not in the seventh or sixth centuries at all, but in the Protogeometric (PG) period. Although she recognizes a form of political projection and self-consciousness in the early epigraphical evidence of the seventh and sixth centuries, and the existence of self-identified cities as centers of territorial states, she also sees these things as already "well established and stable institutions," long existing in Cretan polities from earlier periods (2010a, 76). In Wallace's gradualist view, the Archaic period is a phase of expansion of state territories and inter-polity conflict reaffirming preexisting state-level identity structures. Thus, the Archaic material evidence for the city is important, but fundamentally incidental to the origins and development of the state itself (2010a, 76-77). For Wallace, the late seventh and sixth centuries do not really help us see the process of change beyond the formalization of preexisting social structures encouraged by territorial expression and inter-site interaction. The narrative is both vivid and compelling, but even though she acknowledges formal changes in the seventh or sixth centuries, she downplays both the evidence and the ultimate importance of these, arguing in the end, like Morgan and Coulton (1997) before her, that there is no clear or meaningful division between her PG sites and the Archaic city-between the proto-polis and the polis. In a developmental or structural sense (2010b, 341-342), this position echoes the status quo, the mainstream gradualist 
points of view outlined above (Osborne 2005; cf. Preston and Owen, eds., 2009, 3). Furthermore, Wallace pays tribute to the importance of the physical morphology of Archaic urban centers in reinforcing and encouraging the success and growth of emergent Greek poleis, but for Crete, she sees a kind of material restraint, which is a commonplace metanarrative constructed by most historians and archaeologists working in Archaic Crete today (e.g., Whitley 2009, 290; Erickson 2010, 307). While special-function buildings serving supra-household functions existed in both EIA and Archaic contexts (Wallace 2010b, 279), the lack of material evidence-such as zones of identifiable civic buildings-suggests to her the conservatism, stability, and continuity of entrenched sociopolitical institutions as well as the limitations of physical terrain, into and beyond the Archaic period (2010b, 282-283).

In terms of the archaeology of urbanization, the foregoing is surprisingly similar to the view derived from coarse site chronologies and morphologies of intensive survey with similarly ambivalent views of the importance of the material definition of the urban center itself. In a way, the polis is merely an aggregated settlement had already long existed, conceptually, structurally, and physically from the tenth century on. The ninth and eighth centuries should then represent periods of development and phases of entrenchment of different modes of economic and political behavior, the formation and consolidation of clans as corporate groups reinforcing their links to the landscape, and control of both people and surplus. But the Archaic transition itself is understood as a continuation of these systems, rooted in these preexisting structures, and appearing as less of a punctuated phase transition or abrupt instance of positive systemic feedback. In the end, the artifact of the Archaic city is incidental to this protracted pattern of stable settlement nuclei, and its form is a material enhancement of successful examples of preexisting social and political structures.

Wallace's insistence on an urban-model for PG aggregated settlements is intriguing, but even more so are the implications of the motivations of a stratified elite to concentrate in these EIA polities. The conscious construction of the Cretan city (centralized residences of prominent kinship groups) becomes in Wallace's picture, an active social and political process $(2010 \mathrm{a}, 78)$ in which the maintenance of a dominant ideology is both a result of the nucleation of settlement as well as a driving force for social negotiation and material reproduction. This is an important contribution for studies of ancient urbanization. But for Wallace it must have happened in the tenth or ninth centuries, considerably earlier than the generally accepted picture of change in the seventh century Aegean, with cities reaching a fully developed material form by 600 B.C. On Crete, this phase change might also account for the widespread discontinuity of the sixth century on the island, our so-called "Archaic gap" (Kotsonas 2002). While Wallace and I might agree on the concept of a phase-transition in the emergence of post-Bronze age Cretan polities, I think we probably disagree on the chronology and critical nature and dynamics of such a change.

The bigger problem we face with Cretan city-state formation (and the Aegean in general) is that the polis center is normally perceived as not merely a bigger version of 
a town or village, or simply a more elaborate system of social organization or government, but a fundamentally different kind of sociopolitical behavior. As Yoffee (1997, 261) has emphasized, the city-state creates new arenas for social interaction, which are themselves products of that urban interaction. And it is the material evidence for this new intra-site social behavior that interests me. Our problem on Crete may be that the complex interrelationships of prominent kin groups that Wallace talks about are indeed suggested in the EIA archaeological record, but her understanding of the process of change stands somewhat in opposition to Yoffee's normative model. That is, the transition to urban configurations looks like a scaling-up or merely an increase in size or scale of elaboration. And of course the embeddedness of the kinship group as a social and political actor in Cretan cities confounds our usual picture of state formation, in which the apparatus of governance itself should be divorced from such archaic structures. So if the Cretan polis is merely a scaling up of entrenched social and political interactions and institutions, at what point, and to what end, is there an invention of the urban arena for such interactions, the city as a kind of invention or reinvention of itself (Yoffee 1997, 261)?

I think that this urban invention is not only a critical cultural phase transition, but is absolutely essential in mapping the form and history of Cretan cities and sociopolitical structure into the Classical period. That is, even if we acknowledge the consolidation of underlying structures throughout the Early Iron Age, the material elaboration of the city in the Archaic period is not only the articulation or expression of this structure. The physical process of constructing the built environment and new venues for economic and social interaction catalyzed and internally intensified the formation or crystallization of a new kind of sociopolitical identity. The construction of new buildings was a deliberate and active process of social transformation that needs to be explored and explained. The implications of labor mobilization, resource allocation, and spatial interaction alone suggest a radical restructuring of the cultural landscape. I would argue that the material indices of the urban sphere, that is the actual building of the city, are not simply a scaling-up, or part and parcel of a gradual nucleation and social segmentation of EIA aggregated settlements, but an active and deliberate construction of identities, political power, and arenas for their negotiation that were neither required nor took concrete form before the seventh century B.C.

My purpose here is not to deconstruct the idea of PG aggregated settlements being socially or politically significant (or even poleis), but to balance this view with questions of both horizontal and vertical stratigraphic discontinuities. I would say, however, as an aside, that in order to deal critically with the idea of PG or Geometric urbanization, we would need to know the actual structure of the settlements of that period-that is, what these ostensibly large aggregates really looked like. In fact we might have less evidence of tenth- and ninth-century settlement on Crete, than we do of sixth-century; and certainly insufficient data to begin to engage the meaning of patterns of aggregation or nucleation derived from survey. 
On the regional scale, the changes in settlement patterns, and the appearance of new large PG sites are neatly presented by Nowicki (2000, 241-247) and Wallace (2010a), and they are evidently important indications of a transition in settlement structure in the tenth century. But, it is important to keep in mind both the limitations and telescoping perspective of survey. Although contiguous scatters of pottery may extend across thirty or forty hectares at some sites, the actual distribution of material remains, their scale and meaning, by period, remain to be elucidated or at least critically evaluated, as does the evidence of continuity into the seventh or sixth centuries. We still do not know if these sites were urban-like nuclei at all; nor can we visualize the physical forms of the buildings themselves, their periods of occupation, distribution across the sites, or the configuration of non-domestic installations. Do these sites, ranging from ten to forty hectares, such as Papoura, Kalo Chorio Maza, Krousonas Koupo, Rotasi Kephala, or Ligortinos Kephala (as in Wallace 2010a), represent contiguous building, separate groups or neighborhoods with in-field land or open areas in between them, or perhaps discrete clusters of buildings, and at what scale and in what periods? While it is difficult to reliably disaggregate PG and subProtogeometric (Geometric) pottery from Late Minoan (LM) IIIC and Late Geometric (LG), in surface collections, except in certain fine ware forms (such as kraters, cups, or skyphoi), in my experience working on the Kastro at Kavousi, PG surface samples never seem to form a reliable indication of the variability of subsurface or original surface distribution. I do not doubt the presence of a PG phase on these large nucleated sites-Nowicki and Wallace present the evidence for it-I just do not understand its distribution and the form of its contexts, and ultimately its meaning.

But by taking refuge in the lack of evidence, I am not trying to prove Wallace wrong or simply construct a moot point. I would only say that the evidence that we do have from actual excavation, derived principally from the Kastro at Kavousi (Coulson et al. 1997), shows a remarkable stratigraphic discontinuity marking the start of PG; and this perhaps accords well with aspects of Wallace's view of an EPG transitionthe change clearly involved settlement rebuilding and expansion. But on the Kastro, the buildings were constructed tightly within the physical armature of the LM IIIC settlement. A variable pattern is demonstrated at Azoria where some buildings appear to have been abandoned in LM IIIC, while others continued in use, probably continuously modified throughout the Early Iron Age down into the seventh century. While the evidence at Azoria is clouded by the radical rebuilding phase, sometime before 600 B.C., the Kastro shows clearly the long-term development of proximate household groups-discrete clusters of related nuclei forming relatively static constructions well into the seventh century.

Thus the actual global discontinuity in the Kavousi region comes in the latter part of the seventh century, and it represents a tangible break from a pattern of gradually developing small nuclei on various scales: proximate household groups or household clusters on the site level, as well as the clustering of sites on the regional level, probably reflect different static kinship-corporate groups. Their configuration in the 
landscape will have depended on the physical terrain of the sites themselves, in-field land and water resources, cult centers, and proximity to fallow and grazing. A disruption of this pattern does not occur until the transition from the seventh to the sixth centuries with wide-scale abandonment and relocation of both settlement and cemeteries, and a tendency toward nucleation and centralization of settlement, but also the physical transformation of the site of Azoria.

\section{The Construction of the Archaic City and the Problem of Settlement Structure}

My interest here is in reconsidering the value of a materialist perspective for the early Greek city, exploring an example of urbanization as a physical process of cultural production, and invention, or from the gradualists' point of view, reworking of the urban landscape. So while one can argue that the essential social order that defined the structure of the community was in place before the construction of the city, I think that the process of construction was a radical re-formation of economy and community identity and indeed the political experience and consciousness of its inhabitants. Regardless of whether or not this material change was coterminous with a threshold of global sociopolitical change-expanding territorial interests, inter-polity competition and increased warfare-the critical scale at which inter-site and interregional economies were functioning in the Archaic period remains to be explored. If we consider the material elaboration of the city as only the end result of a gradual process of intensification of interregional interactions, or a kind of enhancement of preexisting modes of social or political expression, then we will never be able to move the discourse beyond the reductive circularity of the systemic framework of models like peer-polity interaction.

At the end of the seventh century, the act of rebuilding Azoria represents transformative sociopolitical behavior, a significant reconstitution of Iron Age culture, and a conscious strategy of cultural production. The question is the ultimate usefulness of seeing the creation of new forms of community interrelationships and new patterns of economic and social interaction as passive responses to regional inter-polity social and economic competition or conflict, or even as the external projection of preexisting power hierarchies or identity structures to similarly-forming regional polities. If the new city is the fundamental reconfiguration and articulation of interrelationships on the intra-site level, I wonder if the act of constructing the city itself is not also an important catalyst for inter-site interactions and politics.

Although we might predict a level of complexity by our perception of settlement size, it is perhaps not as much the perceived scale of the nucleation as the character of the aggregation, that is, the actual structure of the settlement on the ground and through time. The form of settlement is conditioned by terrain, topography, resource 
availability and numerous cultural variables; but the specific structure of the settlement, on the site-level, and indications of intra-site communication and interaction, should provide a useful framework, or at least a baseline, for modeling the function of aggregated sites, and in this case, the meaning of both Early Iron Age and Archaic nucleation. At the site of Azoria, excavation has revealed four fundamental changes to the structure of settlement that we can now place in a stratigraphic horizon at end of the seventh century B.C. Although we are working to refine the chronology of this change through stratigraphic soundings, a date in the last quarter of the seventh century accords remarkably well with Kotsonas's $(2002,62)$ inferential date of about 630 B.C. for initial transformations in central Crete.

The first change is a widespread rebuilding of the site, involving the reconfiguration of the plan of the settlement and the reorganization of domestic and communal spaces. There is evidence for a significant increase in the scale of construction and the labor investment in building practices. The second change is in the form of residential space, which represents a shift from gradually developing proximate or co-residential compounds (or house clusters) that characterize the Early Iron Age pattern in the region, to large single households that are complex in form and integrated into the overall plan of the center. The appearance of the Archaic houses, in most cases clearly concealing or destroying the underlying Early Iron Age settlement remains, indicates fundamental changes in the way in which households were constructed, perceived, and operated as social actors in the community; and as economic and political agents in the region.

The third change is the construction of public buildings. These are new architectural forms and new kinds of buildings, occupying the center of the site, and forming a zone of communal space extending across much of the west and south slopes of the South Acropolis. We are still exploring the spatial limits and architectural details of these buildings, and their formal and spatial interrelationships; but it is clear that they were designed to accommodate large groups of people, and centralized both the storage and preparation of food in considerable quantities.

The fourth change is internal, contextual and behavioral, in a sense informing our picture of the function of new settlement and building forms. It involves changes in the way agropastoral resources were produced, mobilized, stored, and consumed. Although we normally qualify the changes as economic in the sense of the management of agricultural staples and surpluses by various sectors or levels of a presumably agroliterate sociopolitical structure, the changes in foodways on the level of the household and civic building may help us to understand new patterns of intra-site interactions and relationships that formed the social and political organization of the city.

Although each of these changes in structure, in the seventh century, might indicate on the surface of things a scaling-up of preexisting or formative modes of behavior, I think that this is first yet to be proven archaeologically. The changes may, however, serve to demonstrate new ways of structuring, organizing and experiencing intra-community relationships. I would argue that the process of constructing these 
spaces, and the city itself, created a new political consciousness of place, and established or reified new patterns of sociopolitical interaction. The phase transition was a purposive redirection of resources and reshaping of power relationships in many ways in direct opposition to the Early Iron Age settlement structure and regional community identity. Thus, I see urbanization at Azoria as not merely a new material expression of the regional community, catalyzed by increased interregional and extraregional economic interaction and territorial expansion; but rather as a fundamental transformation of ways of living and interacting. In the experience of the inhabitants themselves, the acts of abandonment, aggregation, destruction, construction, and the physical restructuring of the built environment were dynamic forms and expressions of the processes of social negotiation and political reorganization.

If poleis (or urban polities) existed from PG to LG on Crete, there is no compelling archaeological evidence for the kind of active and dynamic restructuring of social and political space that we see in seventh century. In fact, the stability and constancy of EIA settlement systems might indicate the opposite to be true. These were by and large long-lived aggregated settlements, with static and stable household groups and communal buildings of the scale of the hearth temple or house temple (Prent 2007) - the latter, in most cases established as early as PG, is the most interesting as it reflects both the longevity of the Early Iron Age community, and the deep history and entrenchment of its social and political organization. It perhaps comes closest to a supra-household institution, seamlessly integrating community cult in socially-segregated dining rooms that probably combined ritual and political activities. Although we need more evidence from excavation to make this argument, well known archaeological correlates are apparent throughout the island: the shift in the locations of temples and cult places; the construction of inscriptions into temple walls that face out onto agoras or public squares; the abandonment of cemeteries and changes in patterns of necrotaphic consumption; the rapid scaling down and eventual abandonment and relocation of settlements are all indications of a major and surprisingly rapid restructuring of the cultural landscape in the eighth and seventh centuries (Kotsonas 2002; Gaignerot-Driessen 2013; forthcoming; Haggis 2014b).

\section{The Archaic Houses}

The Archaic houses at Azoria are new foundations in the late seventh century. They seem to form single households, with clearly defined food-processing areas (kitchens), storage facilities (storerooms), and multi-purpose living rooms (halls) (Haggis et al. 2011b). Not only has the size of the residential unit increased, but the organization of household space has changed as well. A fascinating development is the abandonment of the central "hearth-room," the combined living, working, and foodproducing area of Late Minoan IIIC-EIA, and later Hellenistic houses on the island. 
The Archaic buildings are spatially complex with articulated functional areas. The halls, evidently multipurpose rooms that were used for drinking and dining, mediated access to storage facilities and the communication between storage and food processing rooms. This tight internal control of storage indicates both the practical and social-symbolic importance of pithos storage, while emphasizing the use of halls for food consumption and redistribution, rather than household industries or primary processing.

Another interesting characteristic of the Archaic houses is that they are formally integrated into the overall structure of the settlement, as it was conceived at the end of the seventh century. Houses were physically built into an armature of concentric spine walls that were constructed systematically across the site, creating distinct but interconnected zones of civic and domestic building. The critical difference here with EIA settlement structure is that the house itself is no longer part of an agglutinative compound, or block of related households, but is now physically distinguishable, relating individually and independently with the broader space of the urban center, rather than dependently through a house cluster. This break from the EIA co-residential group indicates an important social change and reconstitution of the household's identity and relationship with the broader community. Moreover, the formal integration of single residences into a coherent and unified city-wide plan means that there was a direct physical and social relationship to new communal buildings, changing the spatial context of interaction between related households.

The houses on the South Acropolis form a distinctive spatial pattern (fig. 9.1). The Northwest Building, Northeast Building, and South Building 2 (currently under excavation), are positioned on the periphery of the South Acropolis, forming, if not defining the physical edges of the central civic space, which is comprised of a core of contiguous architecture on the south and southwest slopes: the Communal Dining Building, the Monumental Civic Building, and the Service Building (Haggis et al. 2011a). Partly excavated houses on the north and southwest (the North Buildings, and the lowest terrace of the Southwest Buildings) serve to fill out the pattern of residential space ringing the communal complexes. We are still expanding excavation within both civic and residential zones, with the goal of recovering more of the buildings as well as clarifying the communication patterns between domestic and public areas of the site. What is clear is that the urban center is composed of a nucleus of contiguous structures on the peak and immediate south and west slopes of the hill, with the houses closely placed but at the edges of this zone. In terms of architectural definition and spatial organization, it is important to emphasize that houses are constructed along with the civic complexes, and both are deliberately integrated into the unified design of the South Acropolis. At Azoria, it is clear that domestic architecture is "civic," in the sense of being built as part of an overall plan and community investment in the construction of the urban environment.

The best-preserved examples of houses-the Northwest and Northeast Buildings-each have large halls, spacious kitchens equipped with built hearths, and dedi- 


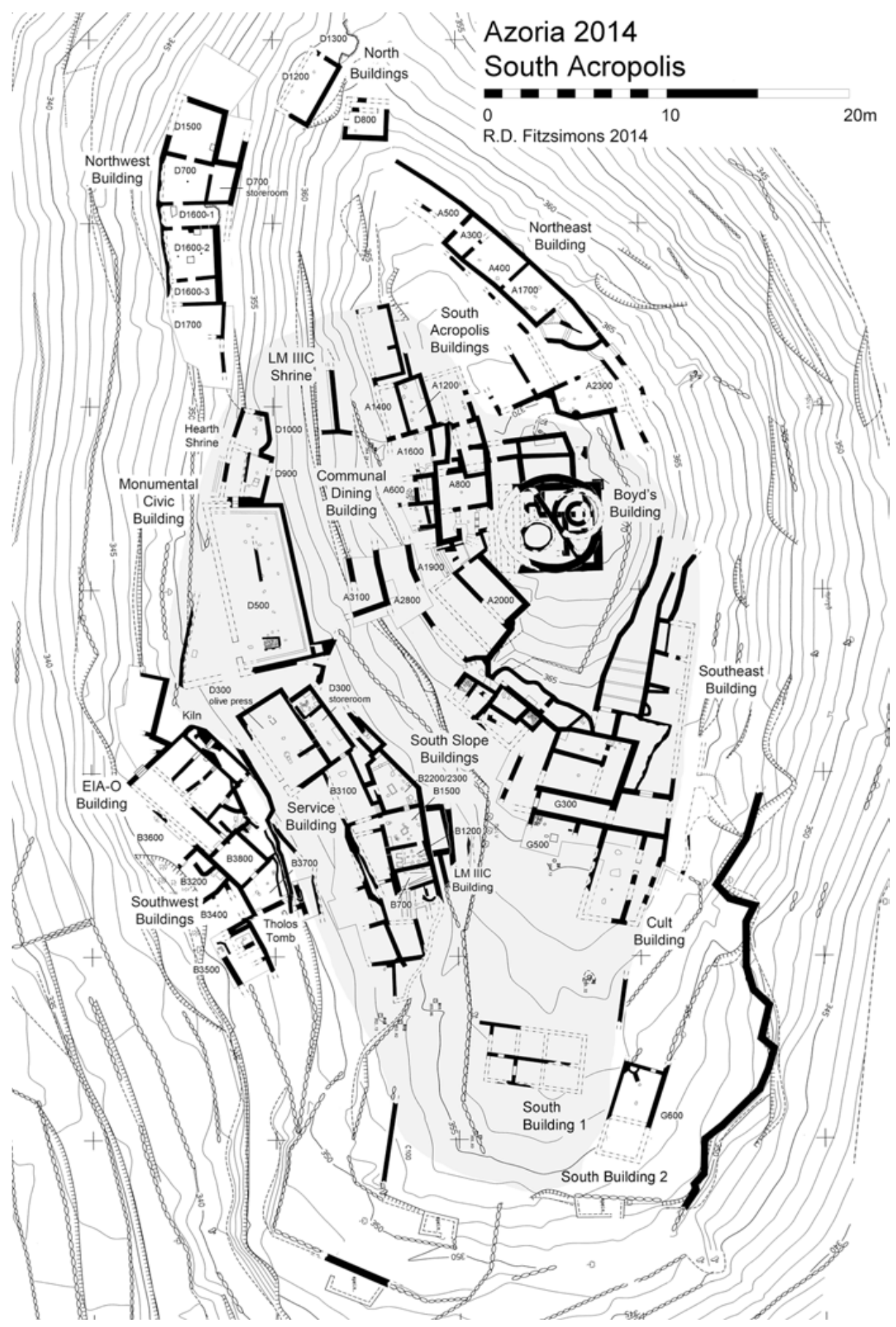

Figure 9.1: State plan of Azoria South Acropolis: projected area of civic space shaded (after drawing of R.D. Fitzsimons, 2014). 


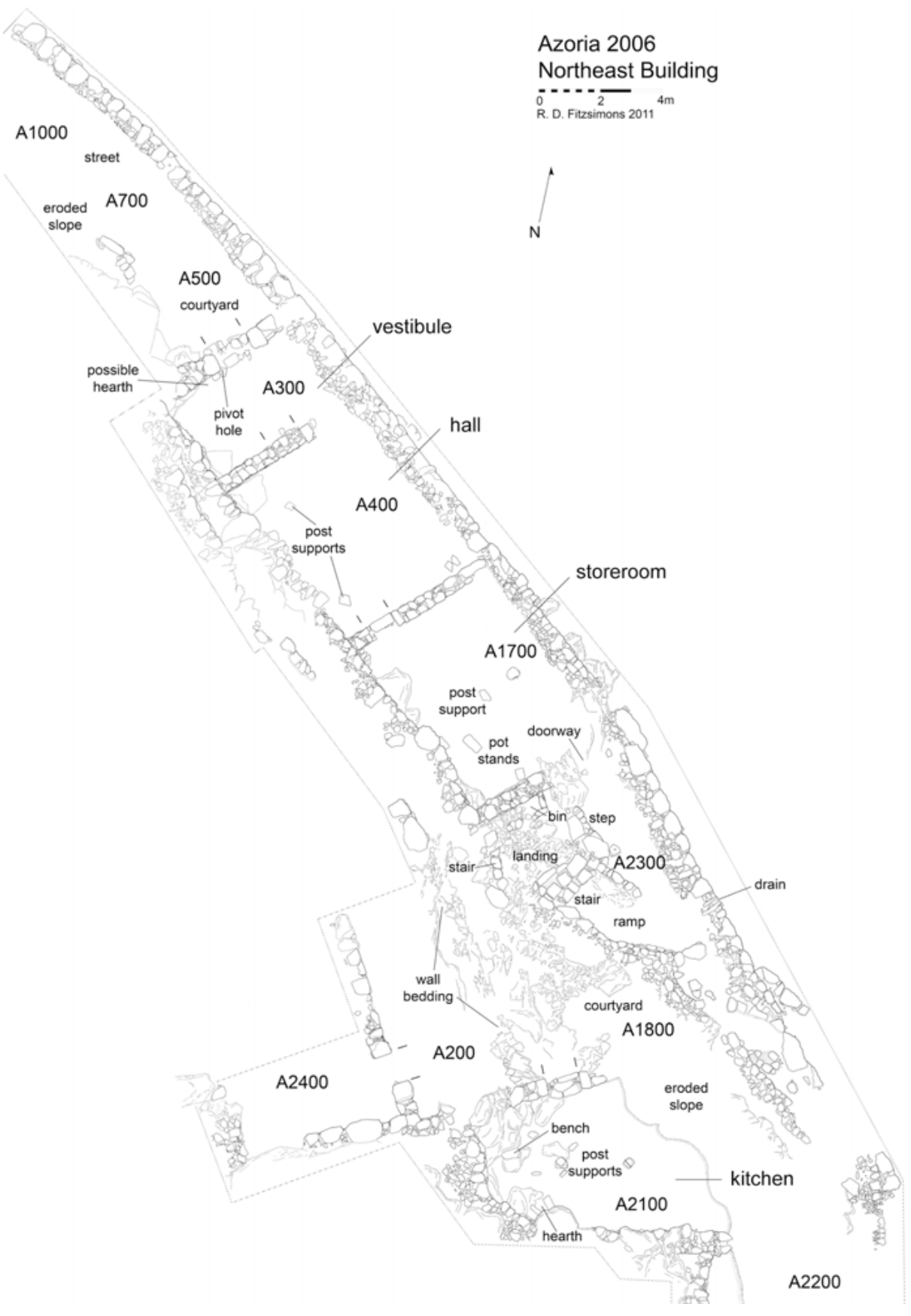

Figure 9.2: Northeast Building (drawing R.D. Fitzsimons). 
cated storage facilities, and while there is evidence for lateral cycling and curation at the time of the early fifth-century destruction of the site, there are sufficiently preserved assemblages to establish regular patterns of use. The total or maximum storage capacities of the houses at the time of destruction are admittedly difficult to determine because of preservation; abandonment formation processes; the variety of different sizes and types storage vessels recovered (including pithoi, smaller jars, amphoras, and hydrias); the likelihood of a range of foods that may not survive archaeologically, and perishable containers, such as woven baskets, cloth sacks, animal skin and wooden containers. What is clear, however, is that the storage interests and capabilities of these buildings far exceeded normal self-sufficiency of individual households, suggesting that the social and economic structure of the house-as-household was far more complex than that of a normative agriculturally-based nuclear family (cf. Foxhall 2003, esp. 85). In general, in the classical Aegean, there is tendency to frame archaeological evidence for agricultural behavior in terms of local householdoriented "subsistence" (as in Raaflaub 1993, 43), creating a kind of conceptual opposition to economies of scale, such as regional or extra-regional exchange or "trade." These reductive and opposing frameworks tend to deemphasize or ignore the fundamental household-basis for the agricultural economy of the ancient city, and indeed beg the question of the structure of the household as a social and economic unit.

The storeroom in the Northeast Building (fig. 9.2: A1700) had only two well-preserved pithoi broken on the floor in the southwest corner (fig. 9.3), but there were also fragments of at least four others in the room at the time of abandonment, along with remains of grapes, olives, and various grains and pulses. The size of the room, over thirty-three square meters in area, and the location of stone-slab and worked bedrock pithos stands indicate that the space was meant to accommodate many more storage jars. It is about two thirds larger than the best-preserved storeroom in the Service Building (B700) (fig. 9.1), which contained at least eight pithoi as well as a number of amphoras in situ. Thus for A1700 we estimate a maximum number that could well exceed twenty such vessels, or a volume of about 6,000-8,000 liters, using Christakis' estimated 300-400 liters for Archaic jars at Prophetes Elias (Galanaki et al., this volume).

In the Northwest Building, there were two storerooms of similar size, probably for separate dry and liquid storage (D700E; D1600-3) (fig. 9.4). The combined area of these rooms indicates total committed space roughly equivalent to that of A1700 in the Northeast Building. The D700 storeroom had remains of four pithoi, with two pithos stands in situ (fig. 9.5), but also a variety of preserved foods, including olives, grape, barley, chickpea, poppy, and figs. The D1600-3 storeroom at the south end of the building, probably for liquid storage, had stands for eight pithoi (fig. 9.6), but room for at least nine jars, several (at least six) of which were found in situ fallen from their stands (fig. 9.7)-the number and spacing accords well with the B700 storeroom, which was considerably smaller. Christakis's estimated pithos volume is within the range of the average sizes of jars at Azoria, though we have recovered vessels in 


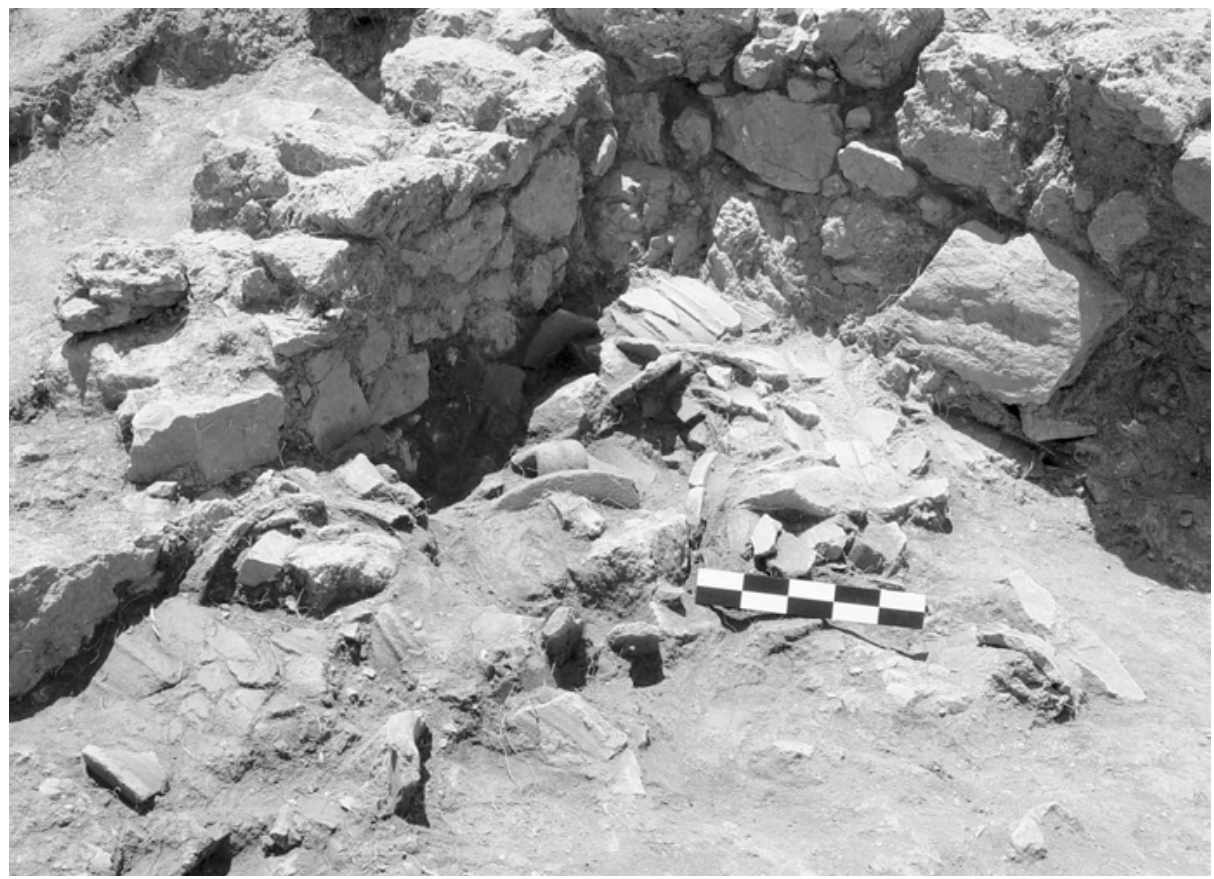

Figure 9.3: Northeast Building (A400): collapsed pithos in storeroom (photo M.S. Mook).

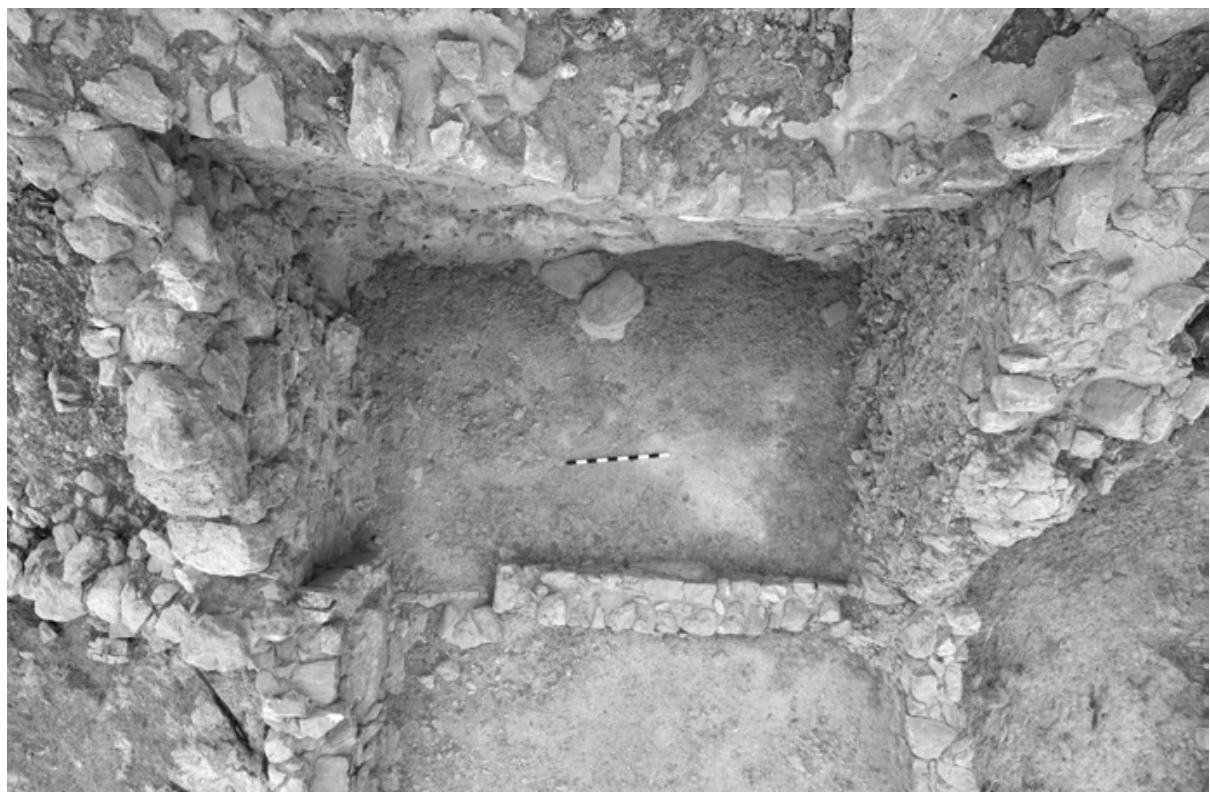

Figure 9.5: Northwest Building: D700 storeroom (photo D. Haggis). 


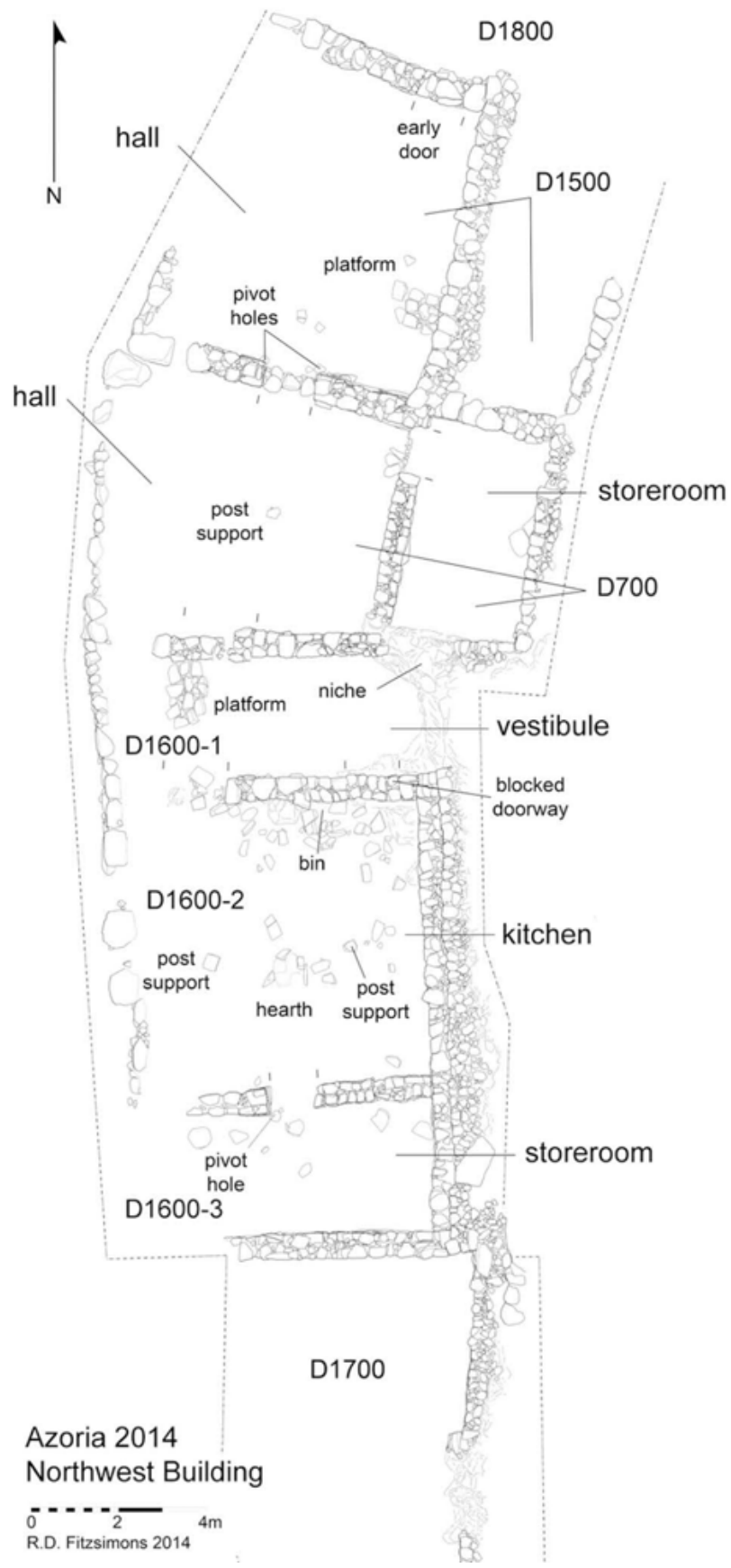

Figure 9.4: Northwest Building (drawing R.D. Fitzsimons). 


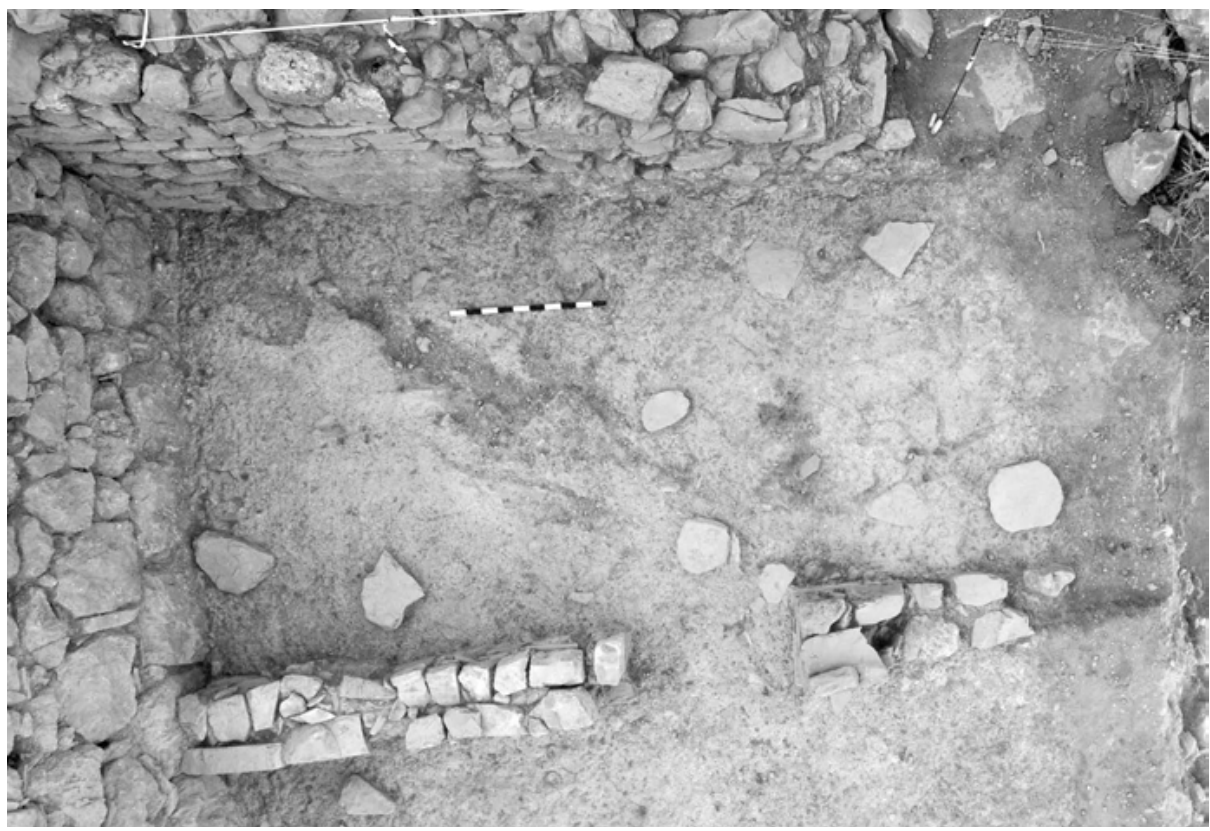

Figure 9.6: Northwest Building: D1600-3 storeroom (photo D. Haggis).

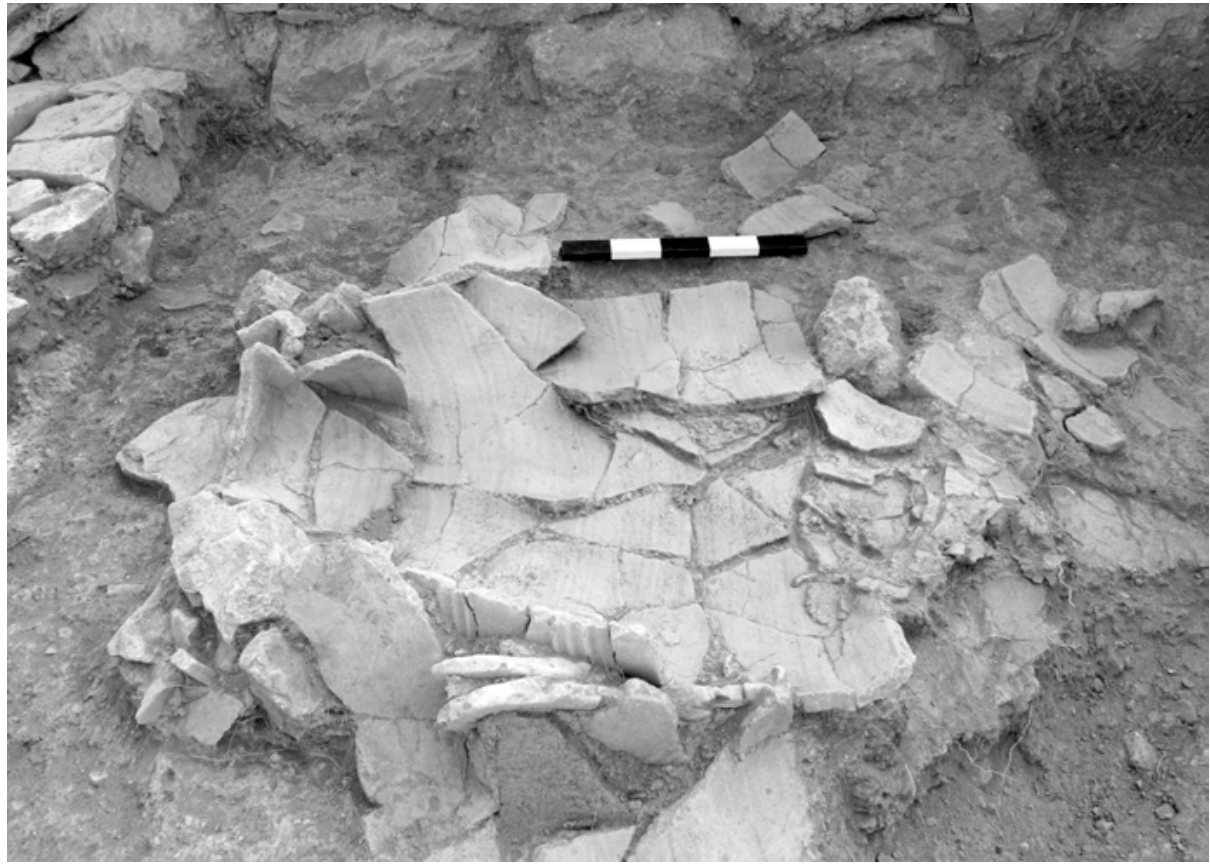

Figure 9.7: Northwest Building (D1600-3): collapsed pithos on stand (photo D. Haggis). 


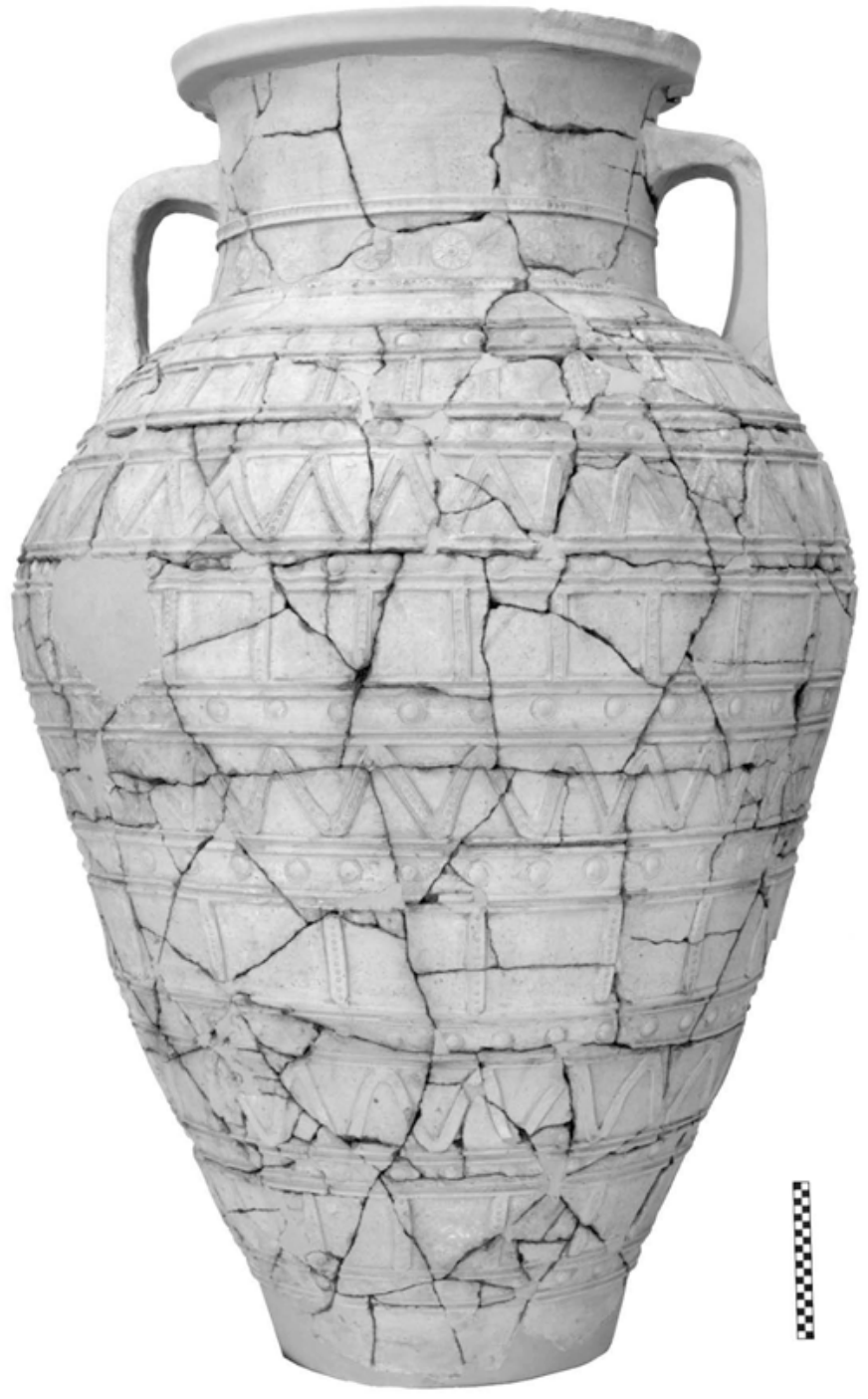

Figure 9.8: Pithos from domestic storeroom in B3600 (photo C. Papanikolopoulos).

houses that had capacities exceeding 500 liters. For example, a well-preserved pithos imported from the neighboring Archaic city of Istron, in the storeroom of a house in the South Slope Buildings (B3600), has a volume of 727 liters (fig. 9.8). It is important to remember that these storage estimates are several times greater than what we expect of the surplus requirements of a single nuclear or stem family for several months-and they represent a conservative minimum household capacity of houses at Azoria. In addition to the dedicated storerooms, the other rooms in the houses, 


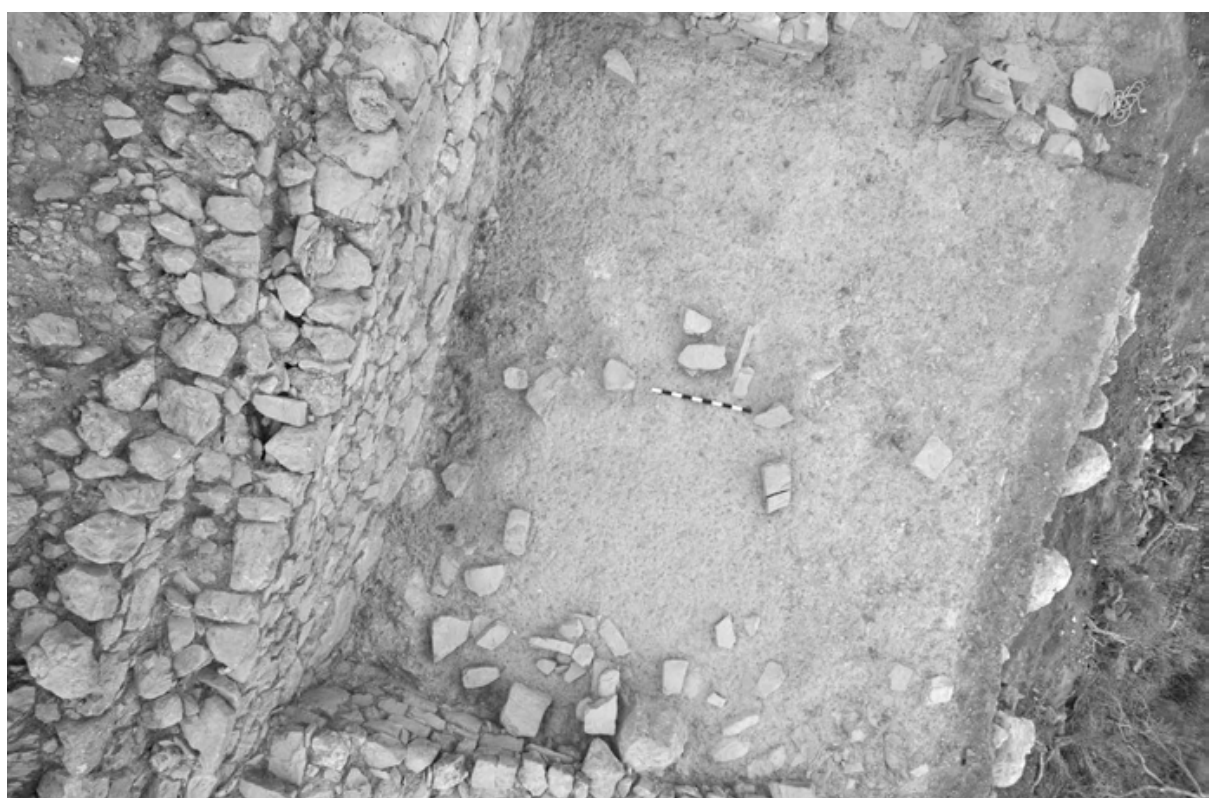

Figure 9.9: Northwest Building: D1600-2 kitchen (photo D. Haggis).

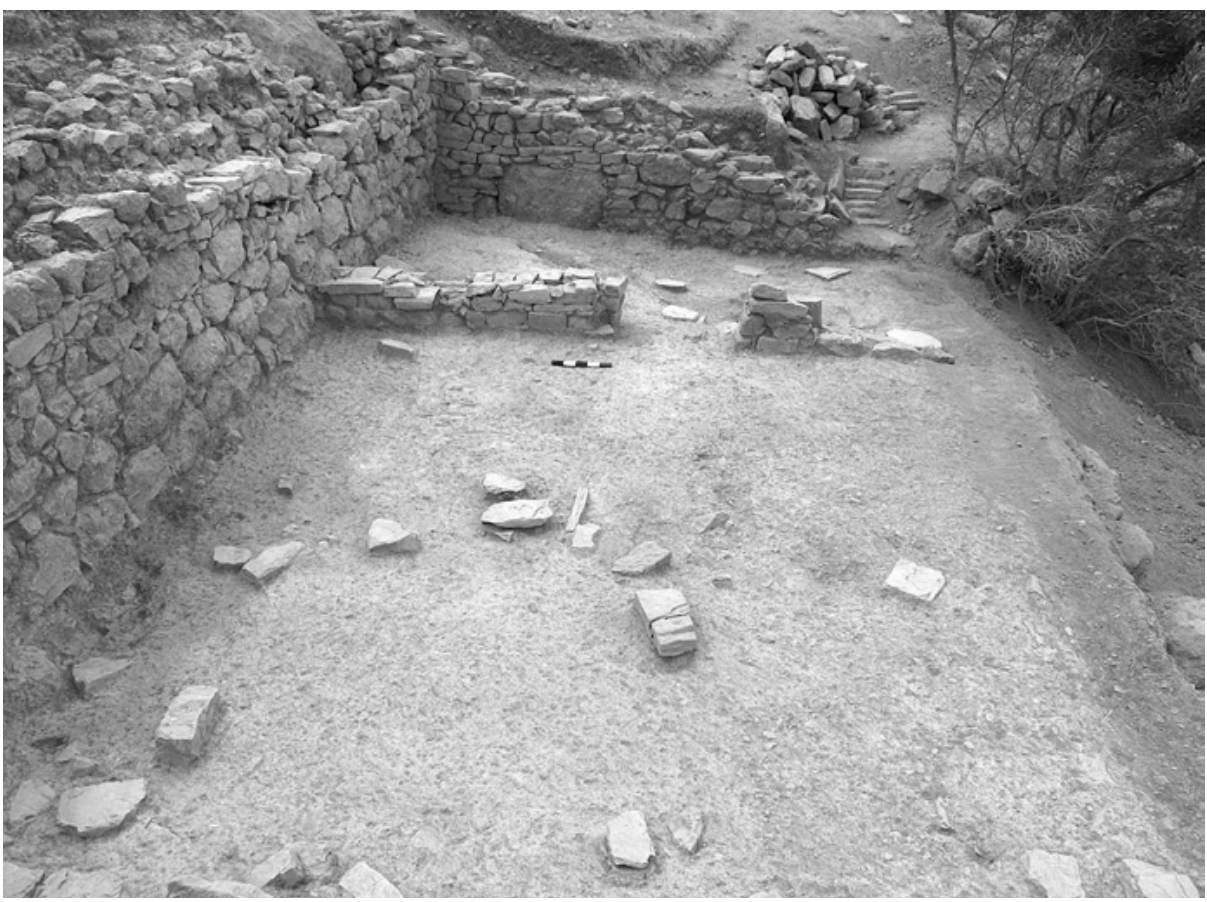

Figure 9.10: Northwest Building: D1600 kitchen and storeroom from north (photo D. Haggis). 


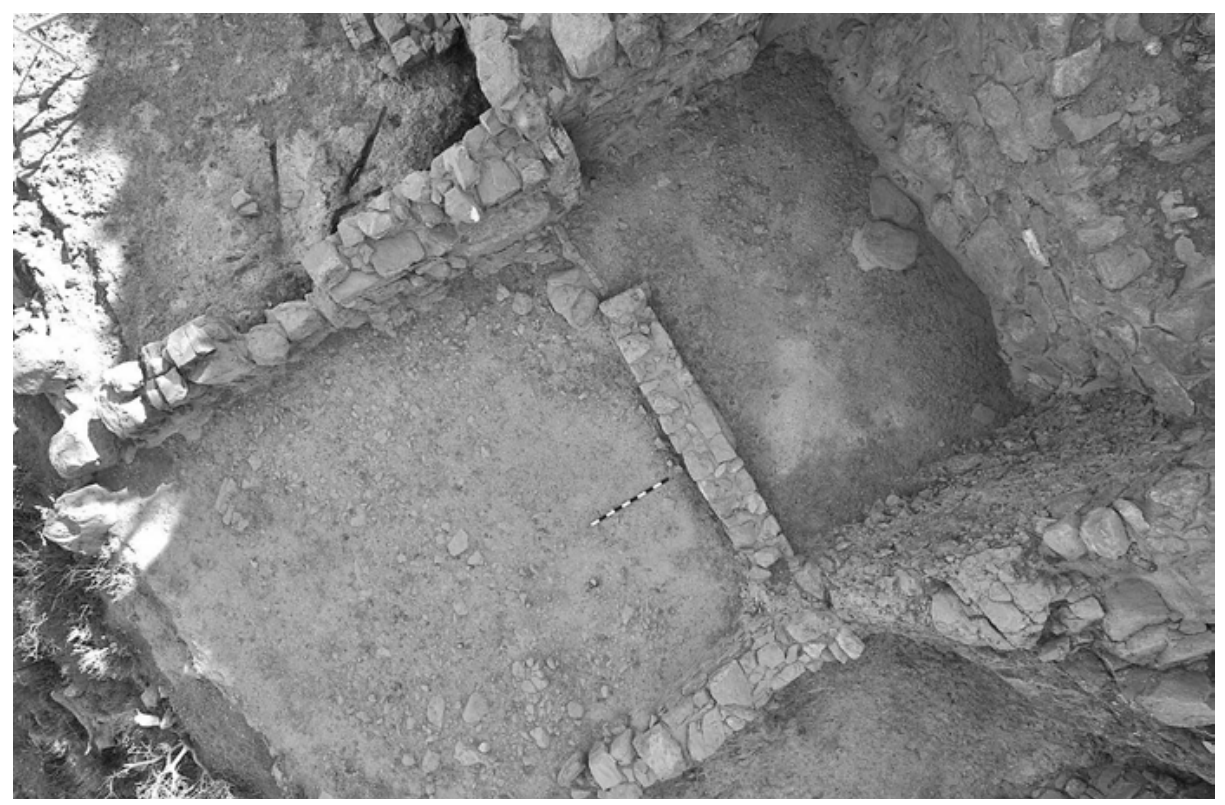

Figure 9.11: Northwest Building: D700 hall and storeroom (photo D. Haggis).

such as kitchens and halls, also contained pithoi, along with a wide range of smallerscale vessels such as table and transport amphoras and hydrias.

The kitchen in the Northwest Building (D1600-2), for example, with a series of at least fifteen pithos stands at its northern end (figs. 10.9, 10.10), could conceivably have contributed a significantly larger food storage capability than the storerooms alone, perhaps increasing the total volume for the house by a third or more. As an estimate, the kitchen of the North Acropolis Building had five pithoi, four transport amphoras, two jars, and three hydrias in use at the time of destruction within the work space of the room (Haggis et al. 2011b, 466-477).

Kitchens in the houses are committed food-processing spaces, and normally separated from the halls by a transitional room, storeroom, or courtyard, or all three, in the case of the Northeast Building (fig. 9.2). Storerooms normally communicate with the halls directly. We have attributed this storeroom-hall connection with the management, control, and display of agricultural goods that would have been brought into the houses in semi-processed form, for shorter-term storage, redistribution, meal preparation, and even immediate consumption (fig. 9.11) (Haggis et al. 2011b, 482483). The implications of the food-storage capacity of the houses are far reaching. It means that the occupants were storing considerable quantities of consumables not only for daily needs of the immediate residence, but for more public (supra-household) or formal drinking and dining within the halls themselves, and most likely for redistribution to dependents and the public stores of the Communal Dining Building and Monumental Civic Building. It also indicates that a good deal of primary surplus 


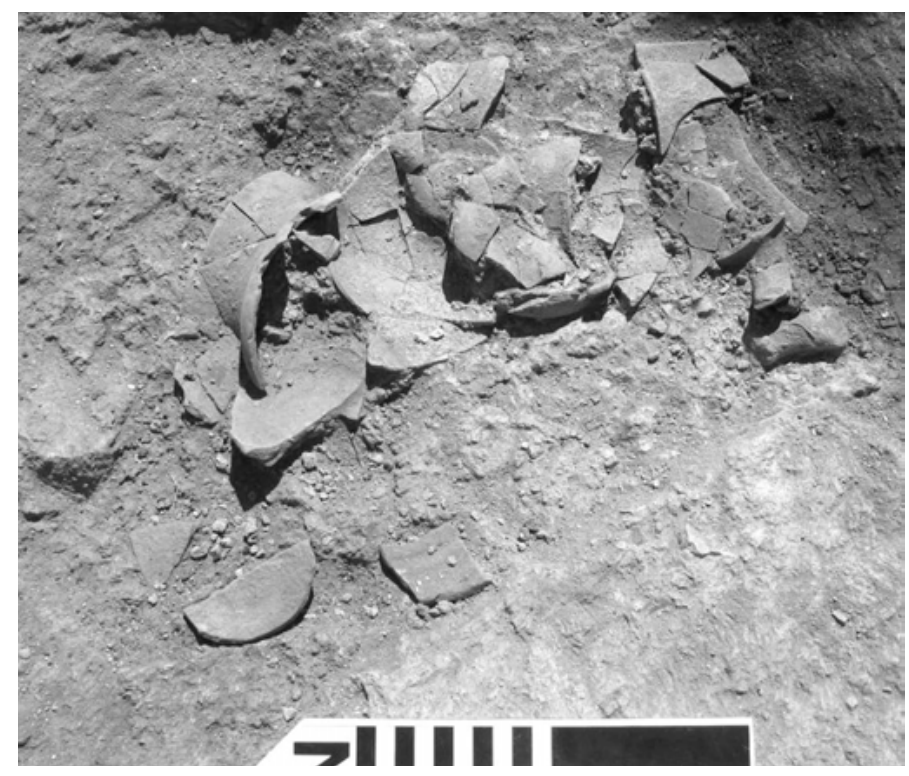

Figure 9.12: Northwest Building (D1500): drinking cup on floor (photo D. Haggis).

storage and processing, and even various scales of distribution, were conducted by dependents living and working some distance from the large urban residences that emerge as estate managers and consumers rather than primary food producers. While Christina Tsoraki's study of the ground-stone tool assemblages is indicating heavier primary processing (in the use of large querns and grinders) in household kitchens than in civic kitchens, Margaret Scarry's recovery of plant remains emphasizes a diverse range of foods, probably surviving as evidence of ready consumables (like oil, wine, fruit, and nuts) and final meal preparation. Large-scale primary grain staple storage is not yet in evidence, perhaps reinforcing the idea that the household surplus does not represent normal long-term subsistence concerns of individual families. The study of food processing implements, pottery, and food remains is in progress, but the patterns to date suggest that houses were socially and economically significant in the construction of civic space as a specific form of urban community-the emphasis is less on the social unit of the nuclear family than on an economic unit and symbolic reference to a larger-scale corporate structure of household.

The halls of the Archaic houses are large in size, and lack permanent stonebuilt features-we assume that wooden benches, chairs, tables and bedding of various kinds might have been used in these spaces. The artifact assemblages of these rooms are mixed, but there are no indications of permanent or impermanent hearths, food processing at any scale, or dedicated industries requiring survivable tools, implements, or installations. Margaret Mook's study of the pottery from these spaces demonstrates very clearly a recurring pattern of kraters, cups, skyphoi, table 
amphoras, hydrias, lekanes and cookpots-with background traces of food debris. The partially-preserved hall in B3400 on the southwest slope included three hydrias, an oinochoe, a fine bowl, a black-gloss skyphos, and at least eight cups. The wellpreserved assemblage in the hall of the North Acropolis Building (E200) had an Attic black-gloss skyphos, a black-figure cup, seven other cups, a Lakonian krater, an olpe, a flask, a fine lid, a hydria, and five chytrai (including two Aiginetan types). While the assemblage from the north hall (D1500) from the Northwest Building (fig. 9.4) has not been completely studied or conserved, there was a tripod basin, an extremely large Lakonian-inspired krater, a pedestalled krater, a cylindrical stand, several blackgloss high-necked cups (fig. 9.12), a small pithos, a jar, hydria, a black-gloss jug, and an imported marble louterion (fig. 9.13). A clear pattern that is emerging from the excavation of halls is that a primary function of these spaces was drinking and dining, with visual and spatial reference to storerooms and pithos storage. Indeed the presence of kraters, including pedestalled and imported forms, as well as fine black-gloss and Attic wares, suggest formal sympotic activities, that in Crete, we usually relegate to public contexts such as the andreion.

The picture of the Archaic houses, at least at this stage of our work, leads us to conclude that the construction of domestic space was a critical process of urbanization. It is not only the spatial complexity of the forms (or social/functional segmentation), or their material elaboration, but indications of a new social and economic organization that recognized and articulated the urban dwelling as an important economic component in the emergent community. The contexts under study have led us to focus on how the household interacted with its broader political and agropastoral environment. In general, the condition of houses at Azoria resonates with Wallace's idea of the formation of elite residences in city centers, which should have belonged to an exclusive citizenry, as a conscious strategy of building or maintaining political and economic power (Wallace 2010b, 336). What Azoria also shows is that the sudden growth in size and complexity of the seventh-century house is mirrored in economic changes suggested by distinctive storage, processing, and consumption patterns. From the perspective of the household, urbanization on Crete may be seen as an active crystallization or perhaps institutionalization of residential groups. Formally integrated into the architecture and physical rebuilding of the South Acropolis, and placed strategically to surround the nucleus of civic buildings (fig. 9.1), the houses would have been potent spatial and visual signifiers, actively serving to shape a new urban landscape, and to codify the sociopolitical identities and economic functions on intra-and inter-household levels. We have argued that the economy and social roles of these urban residences were geared toward management, redistribution, and ritual consumption of food, involving the organization of dependents at the periphery, the control of land and primary production; and the mobilization of foodstuff through the houses and into venues of public rituals of assembly, dining and sacrifice. 

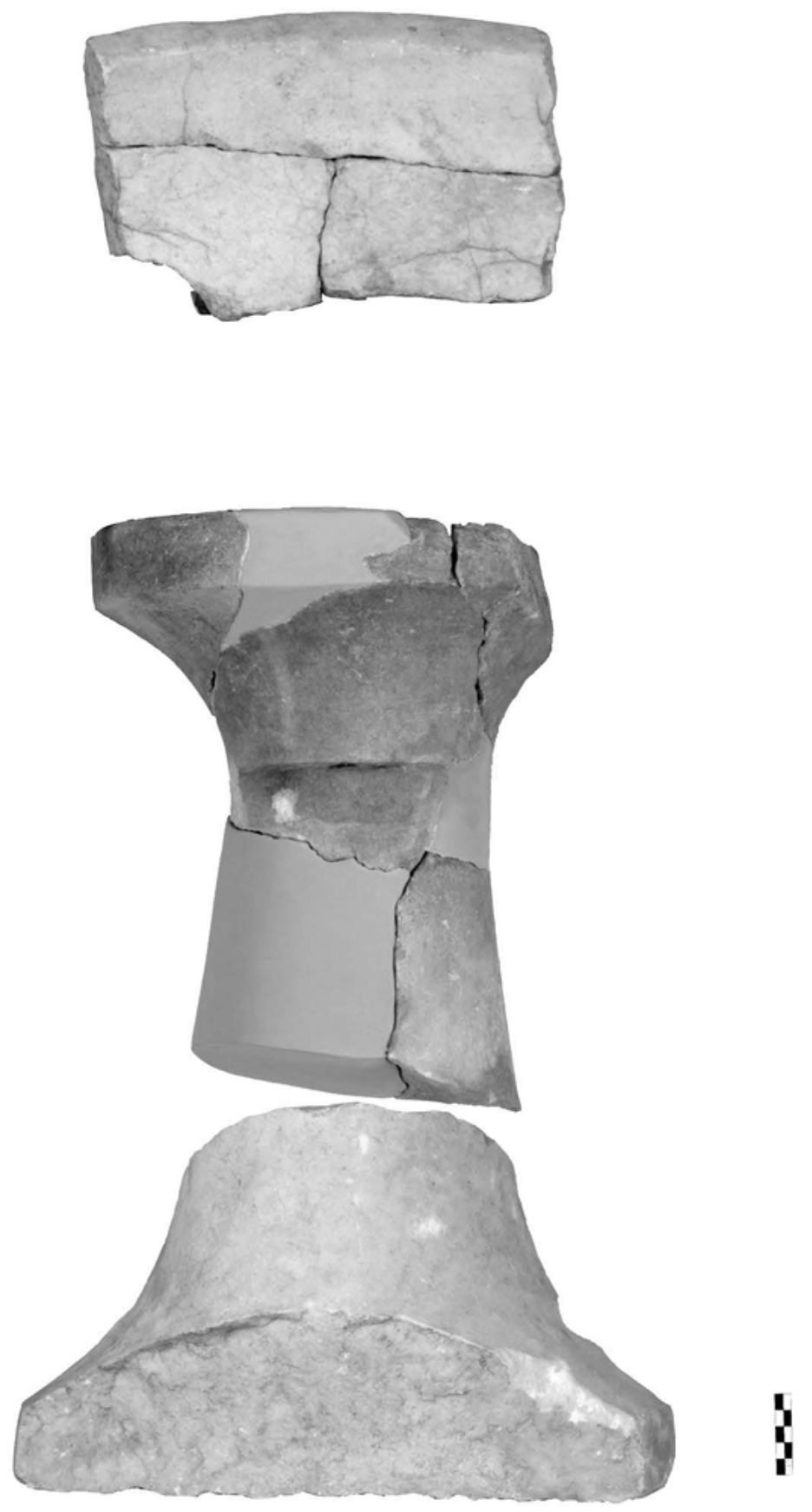

Figure 9.13: Northwest Building (D1500): louterion from hall (photo C. Papanikolopoulos). 


\section{The Public Buildings}

The building of a city at Azoria in the last quarter of the seventh century involved not merely a change of scale or economy, or an intensification of preexisting power hierarchies, but an utter reconstitution and reconstruction of residential and public space. The new urban houses are only one part of a dynamic physical transformation of the landscape-a conscious and deliberate act of recreating the household as an integral and inextricable part of the overall settlement structure. Domestic architecture is incorporated into the system of spine walls, which form a unified structure tying together both civic buildings and residential space. The houses are part and parcel of the urban structure; in the architectural fabric of the city, they would have been visually indistinguishable from civic buildings, except by size and location.

The Archaic phase transition brought with it major changes in the way the inhabitants perceived and constructed their built environment, altering the way that people lived and worked. It also certainly involved a significant cognitive change as well, a reshaping of their settlement history and interrelationships, and how they would have construed and projected their identity and connection with the place. The economy of the Archaic household seems to have been dispersed, multi-local, and centrifugal character. In its multi-focal structure, it would have had to reach out beyond the walls of the house unit in order to connect itself to dependent houses, land, labor, and material resources, in a way creating a more connected rather than integrated urban periphery, and requiring the management and negotiation of the broader social and economic landscape. It also created a weaker and perhaps less stable and mobile corporate identity within the broader community, with households more closely linked to centralizing or "civic" institutions. Evidence for this link between corporate households and the civic institutions of the city is found in the tightly integrated layout of buildings along spine walls, and their close proximity to new buildings used for supra-household activities.

The location, plan, and organization of space within the public buildings points to communal reintegration within carefully regulated systems of participation. An historical perspective would suggest a form of inclusion that necessitated tight controls privileging a narrowly defined citizen class (Erickson 2010, 304-305; Small 2010)-the participants were most likely derived from the urban residences described above. Furthermore, the juxtaposition of civic buildings at the site, the Communal Dining Building and Monumental Civic Building, suggest different scales and different levels of integration within the notional city center (fig 9.1).

The Communal Dining Building and Monumental Civic Building share certain essential functions, such as large-scale storage, food preparation, communal dining, and public ritual. The two buildings-as we have defined them at this stage of excavation-are actually contiguous constructions occupying the west and southwest slope of the South Acropolis. It is also possible that a large rectangular Archaic building on the summit of the hill, excavated by Harriet Boyd in 1900 (fig 9.1), could be an 


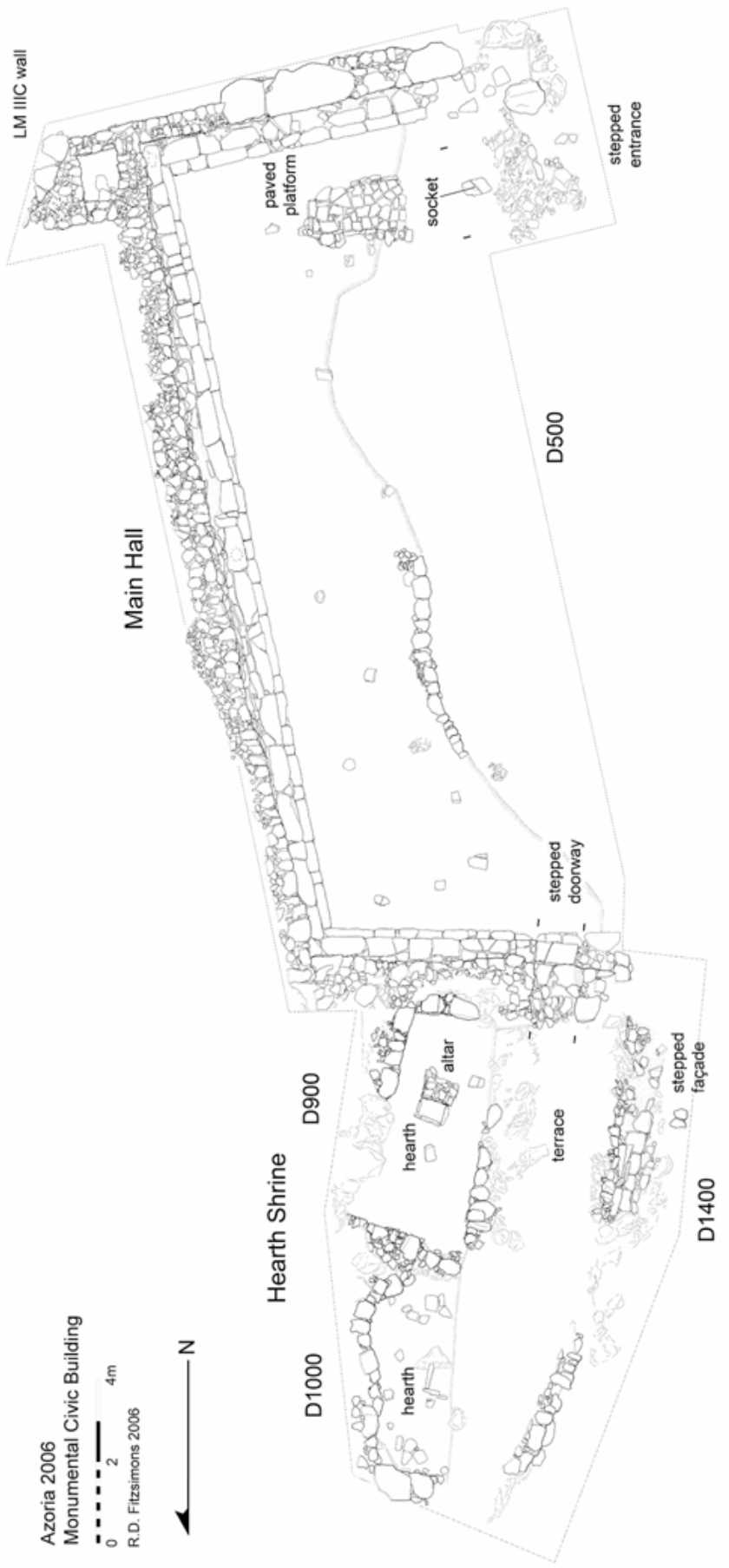

Figure 9.14: Monumental Civic Building (drawing R.D. Fitzsimons). 
extension of this complex, but none of the finds from Boyd's work, and nothing of the stratigraphy of this structure survives today. What we can say is that the civic complex is a cluster of spatially-related buildings, essentially the Communal Dining Building, on the upper west slope; the Monumental Civic Building, immediately below it on the slope; and the Service Building, which because of its proximity and access by a street, communicated directly with the main hall of the Monumental Civic Building. We are still in the process of excavating within this civic zone, so any presentation or interpretation of the overall plan or the relationships between buildings must remain preliminary.

Although we are reasonably certain of the extent of the Monumental Civic Building-the main hall (D500) and shrine building (D900-D1000) (fig. 9.14)-it is clear that the adjoining Service Building was much larger, and had at least two major architectural phases. In general we can say that it consists of a large main hall (D500), about 200 square meters of roofed space, with an elaborate stone-built stepped bench (fig. 9.15), as preserved, running along the north, south and east walls. A doorway and stairway in the north wall led to an upper terrace that contained a two-room shrine, one room with a hearth and bench altar (D900), and the other an adjoining food preparation and store room (D1000) (fig. 9.14). The finds within the main hall suggest public dining activities: a lekane and situla found on the floor containing stews (chickpeas and goat and another with wheat, broad bean and grape); remains of roasted sheep, goat and other animals; cups and a hydria. The direct link to the Hearth Shrine on the north, and three kernoi found within the main hall itself are also certain evidence of ritual functions. Even though it is clear that cult activities are associated with the building, the marginalization of such installations and the emphasis on public assembly and feasting point to other forms of communal congregation. Drawing broadly on historical analogies for activities in Greek civic buildings, it is easy to visualize the integration of cult components in public dining contexts of the andreion and prytaneion. While we might interpret the space in D500 as a public or civic dining hall, it is clear that this would distort the evidence and mask the complexity and importance of its functions.

The adjacent Service Building, immediately to the south of the main hall (fig. 9.1), complicates the picture even more. Here are a series of large-scale food-processing and storage areas: minimally two kitchens with curbed hearths (B1500; B2200); three storerooms (D300; B700; B1200) (fig. 9.16); and an olive press installation (D300). There are at least another four rooms of this complex preserved to the south and east, whose condition and state of excavation do not permit us to assign specific functions. The minimum storage capacity of this building, based only on the number of preserved and identified pithoi (and the same average capacities that we used for the houses), is over 8,000 liters-though it is important to recognize that we have not yet computed the actual sizes of the largest pithoi or the storage potential of small jars and transport amphoras, which are also numerous in the assemblages. The range of foods included wine and olive oil (indicated by intense burning patterns around 


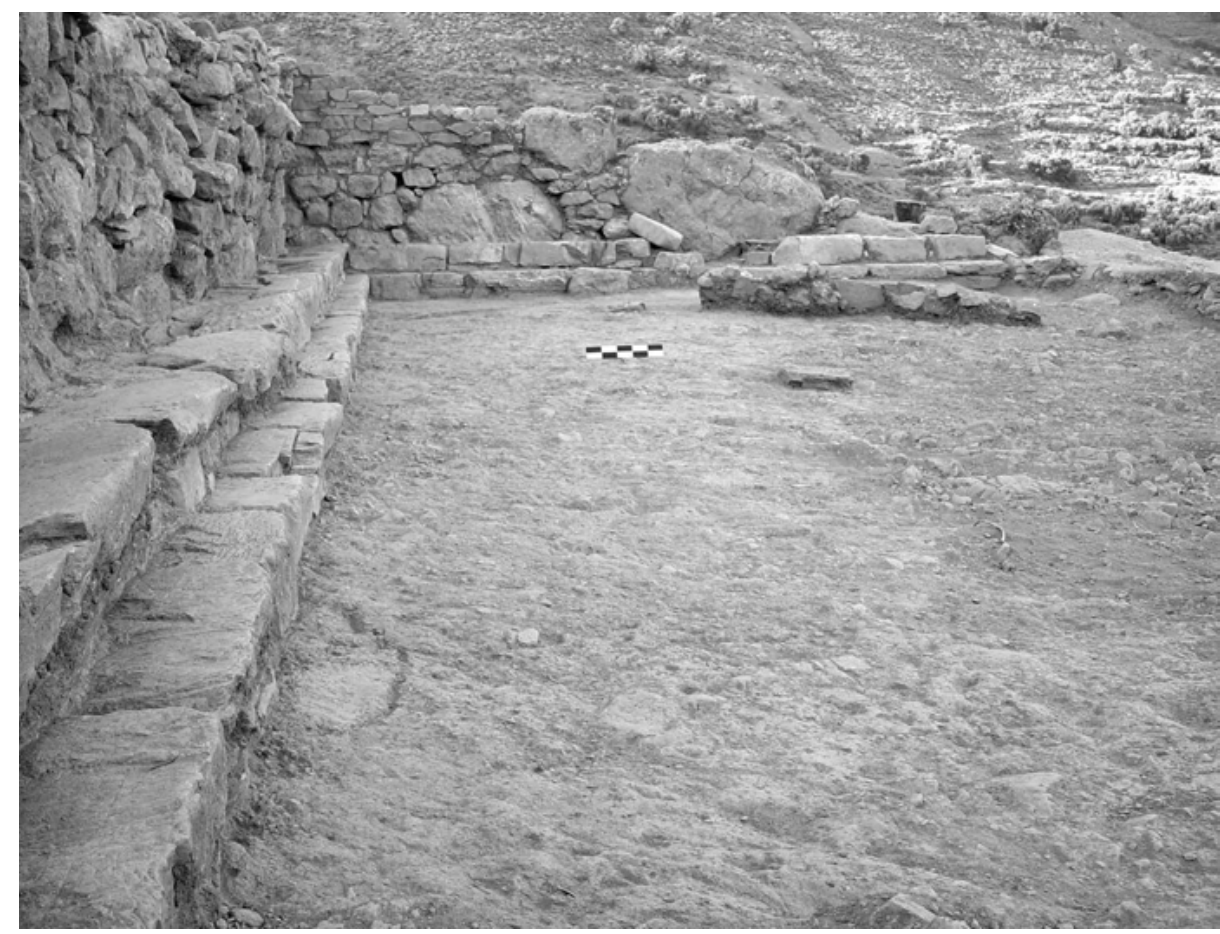

Figure 9.15: Monumental Civic Building: main hall from north (D500) (photo D. Haggis).

some pithoi, and the presence of wine lees), but also whole olives, chickpea, lentil, fig, pear, almond, grapes, and wheat and barley. As with the houses, most of these foods appear to have been brought into the complex for final-stage processing and consumption-we assume that the assemblage indicates short-term storage of for meal preparation, that is, the regular cycling of foods through the complex for specific feasting events conducted in the adjacent hall of the Monumental Civic Building.

The Communal Dining Building, on the slope above the Monumental Civic Building, is evidently much more complex architecturally than its neighbor (fig. 9.17). At this stage of work we cannot determine its full size or complete plan. We had originally exposed a core group of rooms: dining rooms and a cult room (A800, A1900N, and A2000) on an upper terrace; and a row of interconnected kitchens (A1600, A600N, A600S) and storage rooms (A1200, A1400, and A1500) on the terrace below. This building was however much larger-we realized at the time of excavation that we were missing at least half the building, to erosion on the western margin of the lower terrace; to later Hellenistic rebuilding on the hilltop, and the limits of our own excavation sample on the lower western and southern slopes of the peak.

Storage in the Communal Dining Building (fig. 9.17) is widely distributed, and at this stage, given the sample, difficult to quantify in a meaningful way. The best-pre- 


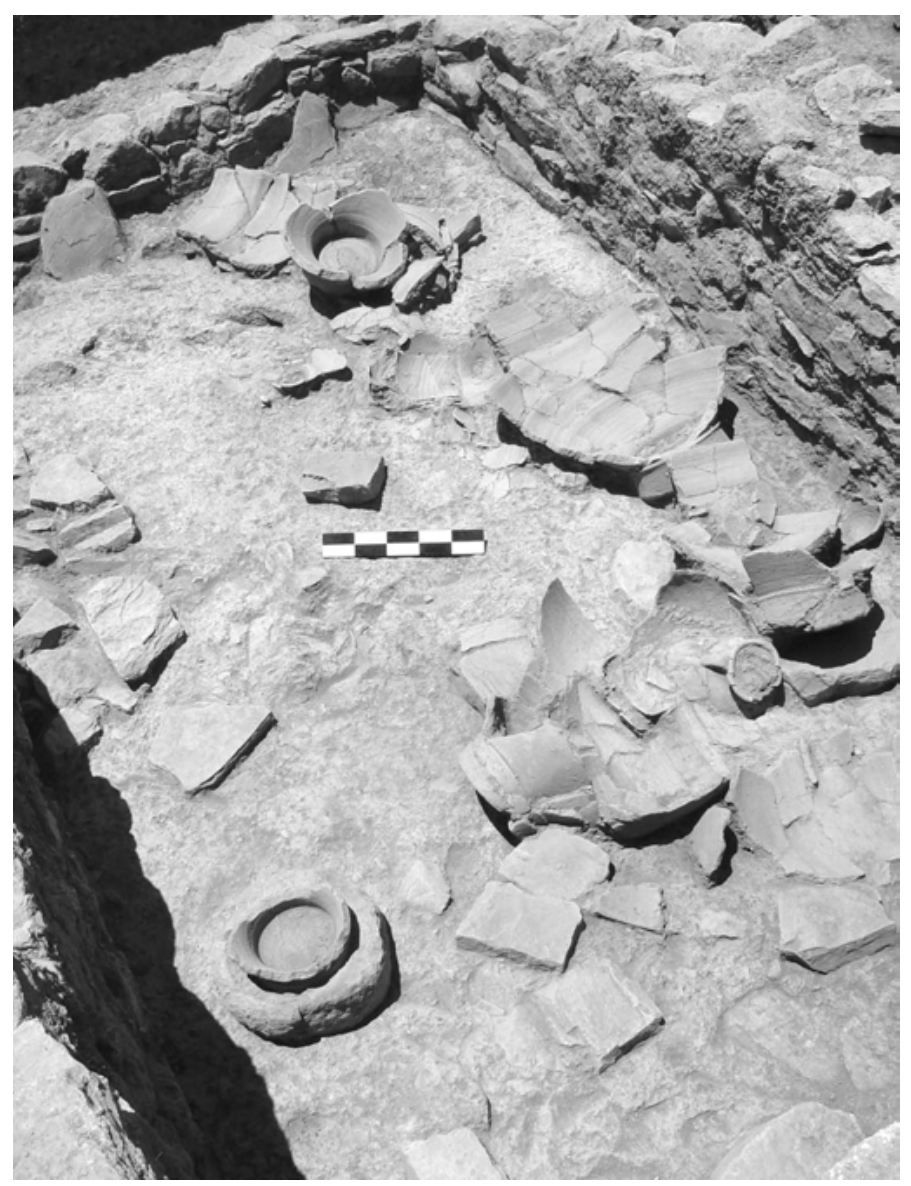

Figure 9.16: Service Building: B700 storeroom (photo M.S. Mook).

served storeroom A1200 had at least seven large pithoi (with concentrations of wine, oil, and olives) at the time of the room's destruction, though with an area of twenty square meters, it could well have accommodated many more vessels. The neighboring rooms, A1400 and A1500 were also evidently storage spaces. There is evidence for grain and pulses in A1500, probably stored in sacks or perishable containers, while A1400 was not sufficiently preserved to derive a meaningful count of pithoi. Small pithoi were also found in one of the kitchens (A1600), in a room off of the altar room in A1900N, and in the upper dining room in A2000. A conservative estimate of pithos storage capacity, based on rooms recovered (and vessels reconstructed) so far, exceeds 5,000 liters at the moment of abandonment, though we have no reason to suspect that this represents the limits of the actual storage space within the building or in all periods of use throughout the sixth century. 


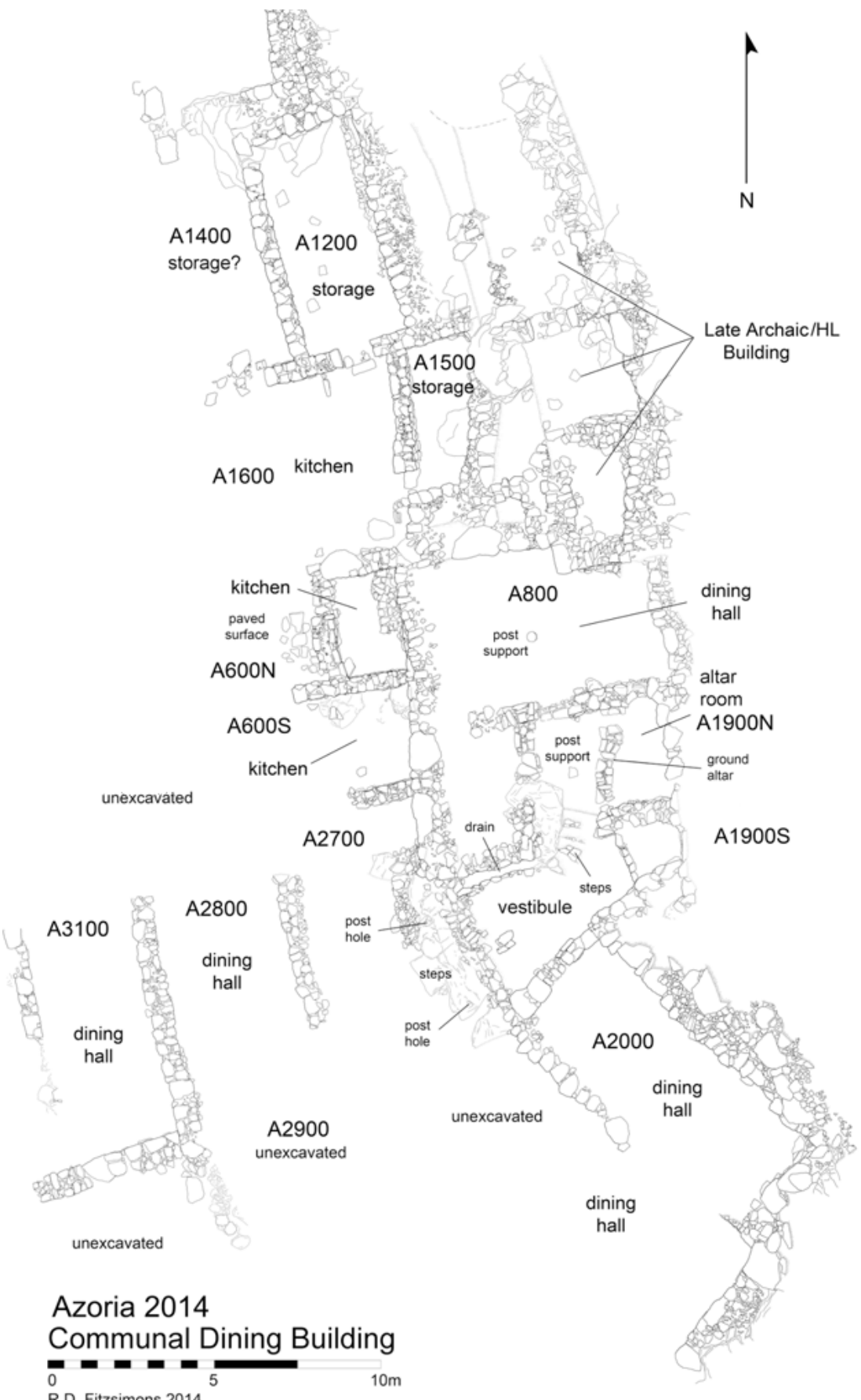

Figure 9.17: Communal Dining Building (drawing R.D. Fitzsimons). 
I emphasize the potential storage capacity of these civic buildings partly because it has become an interest in recent studies exploring the question of economic centralization in Archaic Cretan urban economies (e.g., Erickson 2010, 320; 2011, 388; Watrous and Hadzi-Vallianou 2004, 342-344), in which evidence for surplus should reflect a state-organized system of taxation and redistribution through public feasts. Such approaches have followed a dominant discourse that cautiously avoids assigning historical-cultural terms, such as the andreion, to specific architectural forms for public commensality in Cretan contexts, preferring a multiplicity of fluid and variable contexts, reflecting the perceived complexity of formal drinking and dining practices in the Greek world. Much of this ambivalence understandably stems from our skepticism of reductive formal-functional definitions of specific building types or archaeological contexts (e.g., Sjögren 2008, 84). It should be important, however, to consider not only the total potential volume of pithoi that have survived in excavation samples (as in Erickson 2010; 2011), but also the specific kinds of foods stored, their storage longevity, and ultimately the temporal and cultural variables in systemic contexts of mobilization and consumption practices. That is, to assess the significance of the volume of storage in evidence in archaeological contexts, we would need also to consider the size of the site and potential numbers of donors and consumers; the seasonality of crops; scales of production; effectiveness of the kinds of storage equipment; and perhaps most important, the numbers of potential participants, and even the periods and nature of the events of consumption. All of these factors have potential archaeological correlates, so it is worth pursuing. At this stage of our work at Azoria, we can say the storage capacities of both civic buildings represent a significant suprahousehold or community investment in food mobilization for public consumption. Given the unusual volume of storage, and range of foods stored, we infer that the households may have been vehicles for mobilizing produce into the center and civic complexes.

In the Communal Dining Building, a transition between the dining rooms on the upper terrace, and the kitchens and storerooms on the lower terrace, was facilitated by means of a wide stairway, porch and vestibule in A1900S (fig. 9.17). Moreover, it is now certain that the building originally extended downslope to the west, perhaps as far as the back (east) wall of the main hall of the Monumental Civic Building (fig. 9.1). Here, in 2013 and 2014 we exposed the southern ends two more dining halls, similar in general shape and dimensions to the upper-terrace hall in A2000 (fig. 9.17: A2800 and A3100). While the floor was not preserved in the upper hall (A2800), the adjacent lower hall (A3100) had a well preserved floor, and more interesting, a deep deposit of dining debris-fragments of cups, pouring and serving vessels, krater stands, and animal bones (butchering and food debris)-evidently dumped into the room before the end of the sixth century (fig. 9.18). The range of finds mirrors the assemblages recovered in the dump in A600S, and on the floor surfaces of the dining rooms (A2000) and vestibule (A1900S). Furthermore, on the south slope (south of the South Slope Buildings) we recovered yet another hall, with a similar deposit of dumped dining debris 


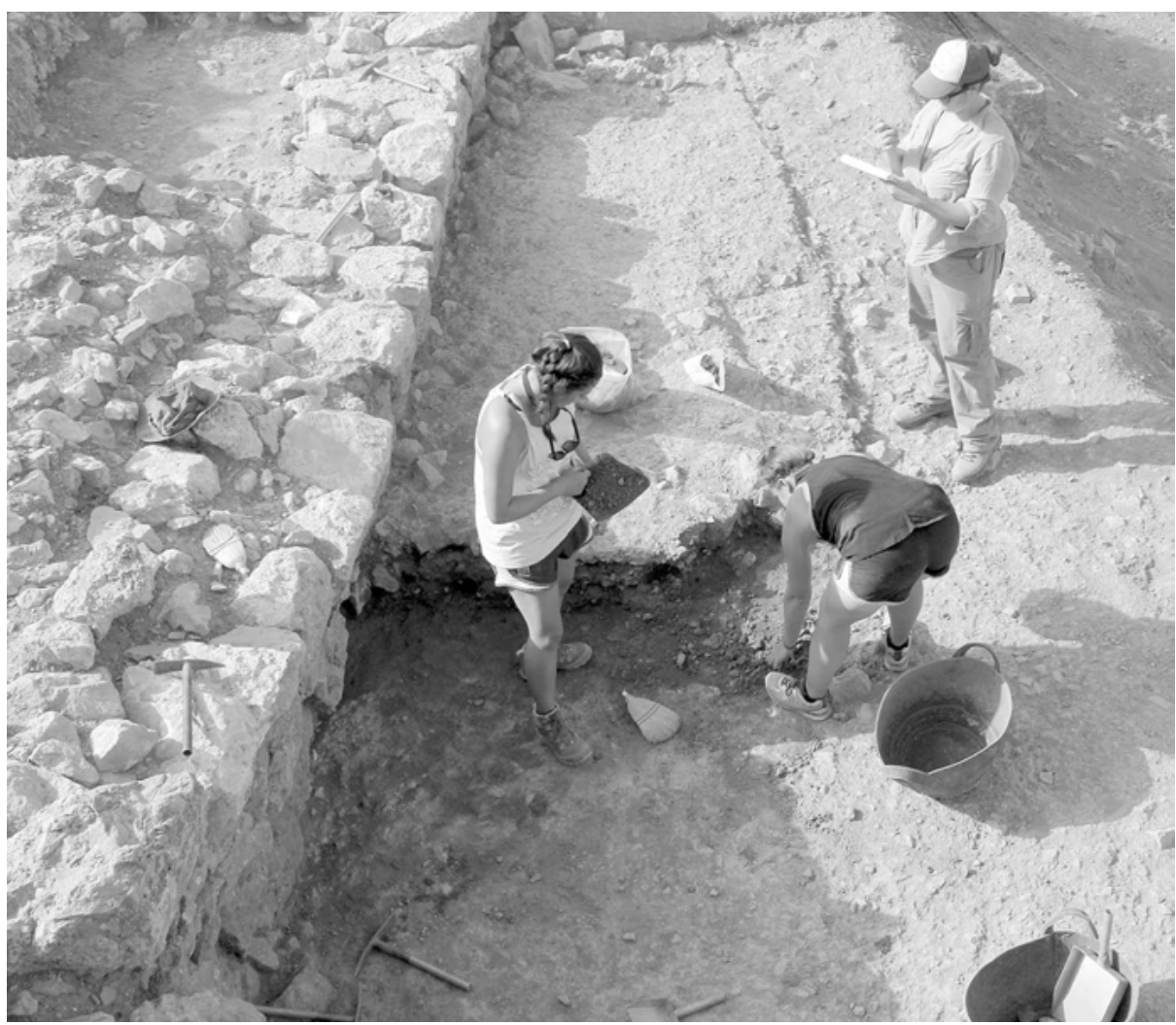

Figure 9.18: Dining room (A3100) with dumped debris, during excavation (photo L. Thompson).

(G300), and an adjacent food processing room in G500 (figs. 9.1, 9.19). This evidence, while preliminary, indicates the possibility that what we have called the Communal Dining Building may actually extend far to the west and south of our original core structure, encompassing the entire west and south slopes of the peak-essentially the entire area lying east of the Monumental Civic Building and the Service Building (fig. 9.1). It was also clearly more complex architecturally than we have thought, with a series of dining rooms extending down the slope in the west and south of the summit of the South Acropolis.

Much more excavation needs to be done in this area of the site, defining architectural spaces, functional assemblages, and patterns of use and communication. It is possible, however, that the three public buildings comprise a contiguously constructed and centralized core of interconnected spaces dedicated to different kinds of administered food storage, processing, and dining activities, and accommodating differently-configured groups of participants. We have commented in earlier reports, that the form of the Monumental Civic Building should have been suitable for more 


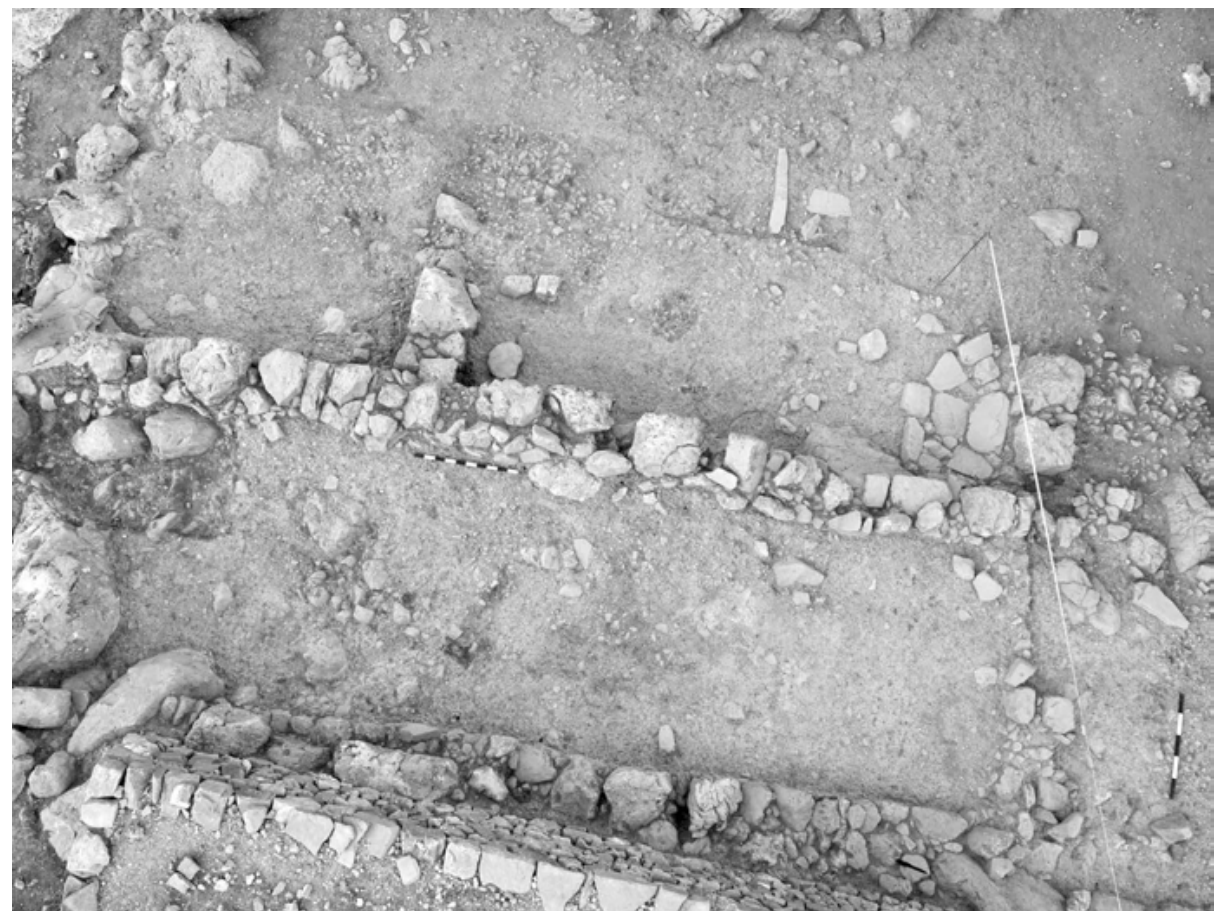

Figure 9.19: South Slope Buildings: G300 dining room; G500 kitchen (photo D. Haggis).

open or communal assemblies, while the Communal Dining Building was for a number of smaller groups of participants. It was more complex, tightly organized, compartmentalized or segmented, with the replication of open halls that-like the main hall of the Monumental Civic Building-were used for public dining, but on a smaller scale. So far only two such rooms have been excavated completely (A800 and the upper room of A2000). It now appears that there were at least four others: A2000 (lower room); A2800, A3100, and possibly G300. All were probably of similar size and shape (about twenty-seven to thirty square meters in area), and each could easily have accommodated groups of about twenty people.

\section{The Archaic Urban Landscape}

The results of excavations at Azoria have demonstrated a significant phase change at the end of the seventh century, evidently transforming the EIA topography, and corresponding to a large-scale discontinuity in the cultural landscape of the region. The transition at Azoria is marked by the construction of new houses and public buildings, and a clear separation and articulation of civic and domestic spaces that 
were nonetheless integrated into a coherent juxtaposition of household and communal space designed to accommodate public feasting. What is remarkable about both houses and public buildings is the unusual investment in food storage, processing, and consumption. We imagine the houses as centers of larger interdependent estates that mobilized agricultural produce and resources for processing and consumption in the city, and ultimately redistribution to dependents, and through tithes, to the storerooms, kitchens and dining rooms of the civic buildings. It is clear enough that the large houses occupy zones in close proximity, but peripheral to the civic buildings, which we can now see occupies a continuous space, from the peak across the west and south slopes of the South Acropolis (fig. 9.1). The locations of these buildings were evidently carefully chosen, negotiated, planned, and constructed as part of the late seventh-century renovation. In the civic sphere, what we have considered discrete buildings-as separate, functionally distinct and interconnected spacesare more complexly integrated architectural ensembles suggesting different groups or configurations of participation. Our preconceptions embedded in the designation of "buildings" as groups of interconnected interior spaces, while a useful form of contextual nomenclature for excavation, affects our interpretation of spaces, and ultimately may be steering and limiting our excavation samples, while obscuring the overall design of the civic zone.

A significant aspect of urbanization was the creation of a number of focal points for mobilizing, storing, and processing food surpluses for various venues and events of domestic and public consumption. Furthermore the patterns of storage and stages of processing evident in the city's elite houses and civic buildings imply the existence of a dispersed and multi-focal structure of larger-scale kinship-corporate groups who under the direction of the urban residences, would have centralized certain food

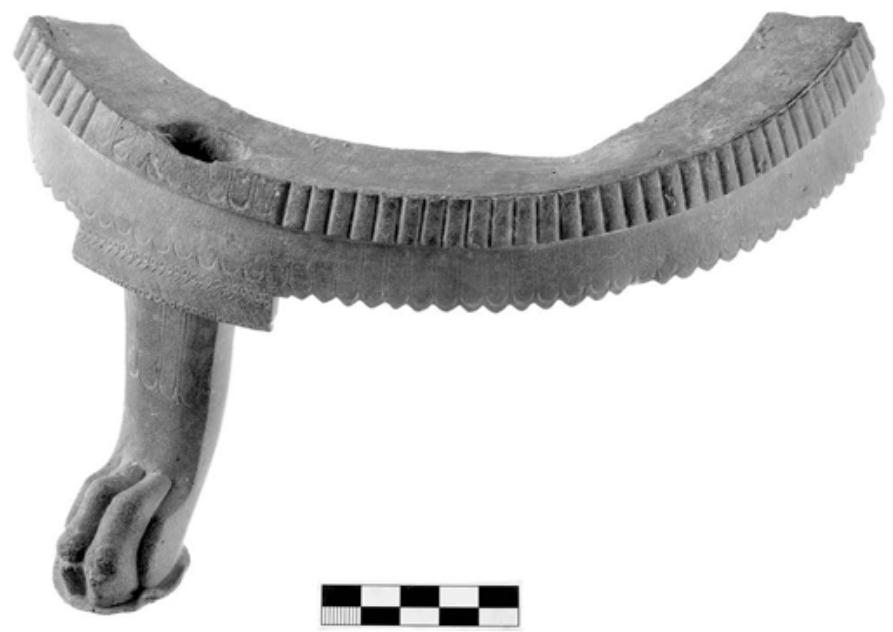

Figure 9.20: Bronze Corinthian podanipter base (B2200/2300) (photo C. Papanikolopoulos). 


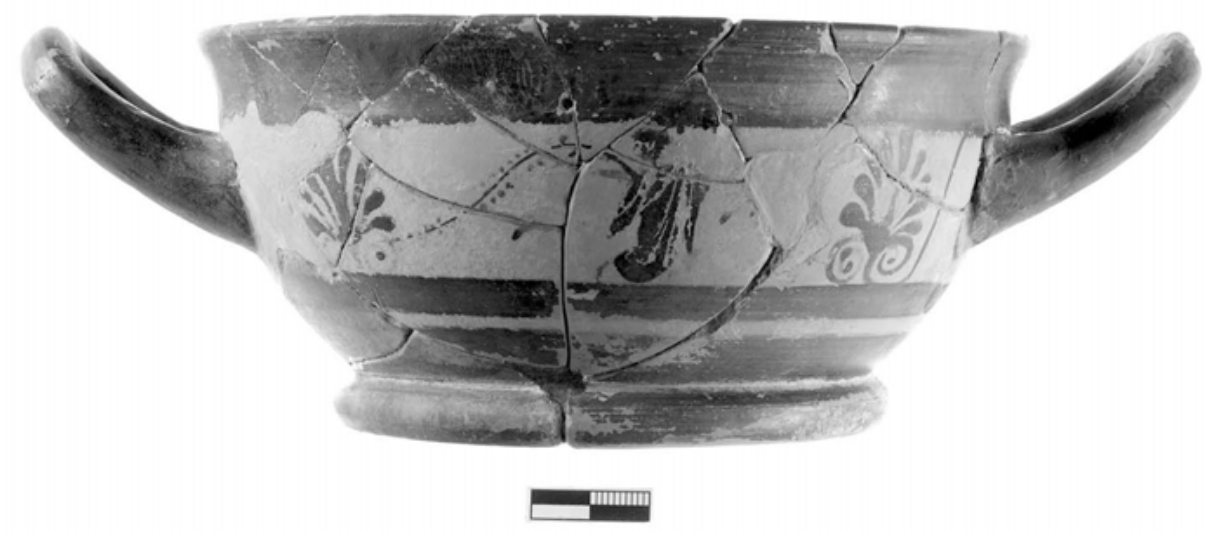

Figure 9.21: Attic black-figure cup-skyphos (B1500) (photo C. Papanikolopoulos).

resources in the city center. The form of these buildings, their physical focal point on the peak of the South Acropolis, and the contexts of storage, processing and consumption suggest the institutionalization of social practices and internal and external projections of power structures. This is not to downplay other components of the urban economy, such as the exchange, distribution, production and consumption of a variety of other goods (e.g., Perlman 2004); indeed Attic, Lakonian, Corinthian, Cycladic, Aiginetan, and other imports are widely attested in both domestic and civic contexts (figs. 9.20, 9.21) (Haggis et al. 2007, 303-305; Brisart 2014, esp. 266-267). Even containers for routine food storage and cooking, such as imported pithoi, amphoras, lekanes, and chytrai, indicate complex exchange patterns within the region and the Aegean (figs. 9.8, 9.22). The point here is rather that the evidence for agricultural production is one contextual source that might allow us to begin modeling in detail social and political relationships within the urban center. Although we cannot visualize the full range of such activities, it is clear that the process of constructing the city, and these specific contexts of food preparation and consumption (and their architectural forms) were central to the formation of the social, political, and economic structure of a new urban center. The buildings themselves were not merely spaces that reintegrated or accommodated a preexisting local Iron Age social system of certain elite households, social groups, events, and ceremonies. The production of the physical forms, the spatial orientation of houses, and the process of building and rebuilding the settlement were social activities that functioned to shape and reaffirm the interrelationships among various participants and a broader urban and rural community. As a result we might resist the tendency to separate processes of urbanization and city-state formation, visualizing a form of developing sociopolitical complexity that displays material patterns, archaeological signatures and contextual correlates of urbanism. 


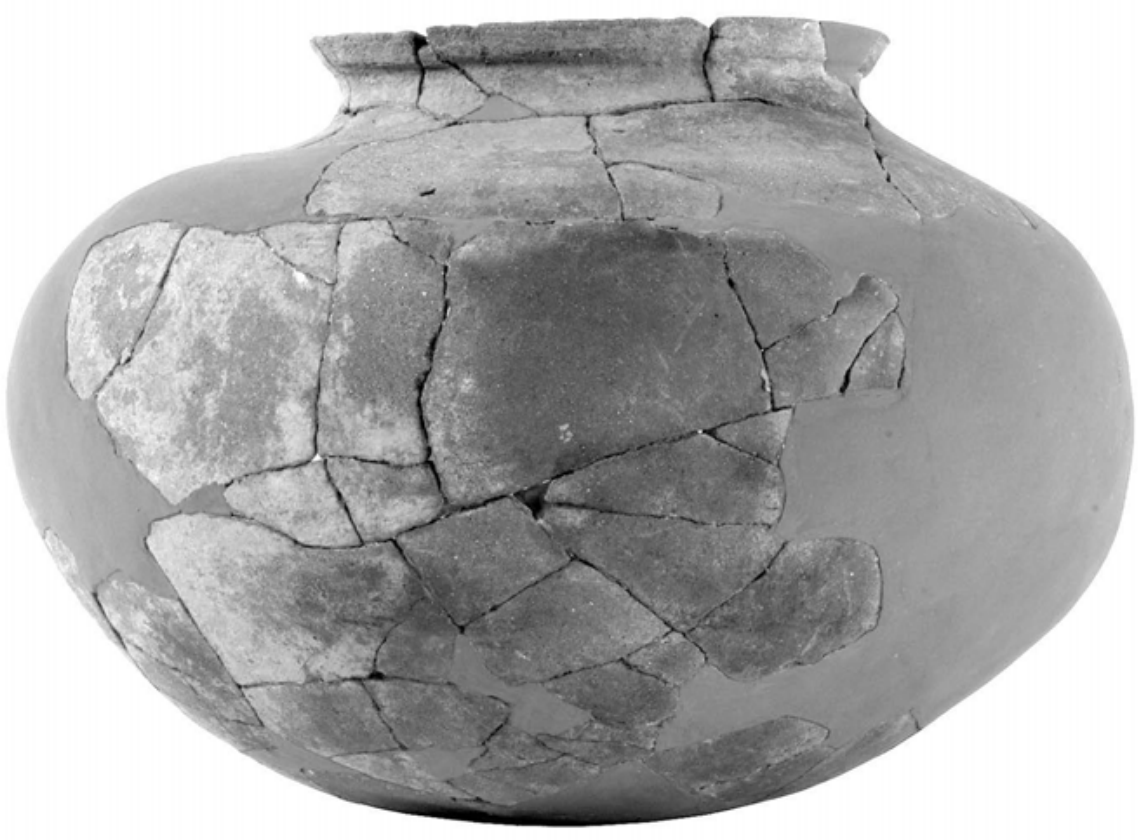

Figure 9.22: Aiginetan chytra (E100) (photo C. Papanikolopoulos).

\section{References}

Bintliff, J.L. 2012. The Complete Archaeology of Greece: From Hunter-Gatherers to the $20^{\text {th }}$ Century A.D., Chichester.

Brisart, T. 2014. "Isolation, Austerity and Fancy Pottery: Acquiring and Using Overseas Imported Fine Wares in $6^{\text {th }}$ - and $5^{\text {th }}$-Century Eastern Crete," in Cultural Practices and Material Culture in Archaic and Classical Crete: Proceedings of the International Conference, Mainz, May 20-21, 2011, O. Pilz and G. Seelentag, eds., Berlin, pp. 263-283.

Coulson, W.D.E., D.C. Haggis, M.S. Mook, and J. Tobin. 1997. "Excavations on the Kastro at Kavousi: An Architectural Overview,” Hesperia 66, pp. 315-390.

Crielaard, J. P. 2013. "Cities," in A Companion to Archaic Greece, K.A. Raaflaub and H. van Wees, eds., Chichester, pp. 349-372.

Erickson, B.L. 2010. Crete in Transition: Pottery Styles and Island History in the Archaic and Classical Periods (Hesperia Suppl. 45), Princeton.

-. 2011. "Public Feasts and Private Symposia in the Archaic and Classical Periods," in ITETA: The Archaeology of Houses and Households in Ancient Crete (Hesperia Suppl. 44), K. Glowacki and N. Vogeikoff-Brogan, eds., Princeton, pp. 381-391.

Foxhall, L. 2003. “Cultures, Landscapes, and Identities in the Mediterranean World," Mediterranean Historical Review 18, pp. 75-92. 
Gaignerot-Driessen, F. 2013. De l'occupation postpalatiale à la cité grecque: le cas du Mirambello (Crète), Ph.D. diss. University of Paris-Sorbonne (Paris IV).

-. Forthcoming. "L'occupation de la baie du Mirambello entre le Minoen Récent IIIA2 et l'époque archaïque: schémas d'implantation dans le territoire, typologie des sites et peuplement," in $D e$ la chaîne du DIKTĖ au massif de l'IDA: géosciences, archéologie et histoire en Crète de l'Âge du Bronze récent à l'époque archaïque, Actes du colloque international pluridisciplinaire, MISHA, Strasbourg, 16-18 octobre 2013, D. Lefèvre-Novaro and M. Ghilardi, eds., Strasbourg.

Greco, E. 2009. "The Urban Plan of Thourioi: Literary Sources and Archaeological Evidence for a Hippodamian City," in Inside the City in the Greek World: Studies of Urbanization from the Bronze Age to the Hellenistic Period, S. Owen and L. Preston, eds., Cambridge, pp. 108-117.

Haggis, D.C. 2013. "Social Organization and Aggregated Settlement Structure in an Archaic Greek City on Crete," in From Prehistoric Villages to Cities: Settlement Aggregation and Community Transformation, J. Birch, ed., New York, pp. 63-86.

-. 2014a. "Excavations at Azoria and Stratigraphic Evidence for the Restructuring of Cretan Landscapes ca. 600 BC," in Cultural Practices and Material Culture in Archaic and Classical Crete: Proceedings of the International Conference, Mainz, May 20-21, 2011, 0. Pilz and G. Seelentag, eds., Berlin, pp. 11-39.

-. 2014b. "Azoria and Archaic Urbanization," in Cretan Cities: Formation and Transformation. (Aegis 7), F. Gaignerot-Driessen and J. Driessen eds., Louvain-la-Neuve, pp. 119-139.

Haggis, D.C., M.S. Mook, R.D. Fitzsimons, C.M. Scarry, L.M. Snyder, E. Stefanakis, and W.C. West III. 2007. "Excavations at Azoria, 2003-2004, Part1: The Archaic Civic Complex," Hesperia 76, pp. 243-321.

Haggis, D.C., M.S. Mook, R.D. Fitzsimons, C.M. Scarry, L.M. Snyder and W.C. West. 2011a. "Excavations in the Archaic Civic Buildings at Azoria in 2005-2006," Hesperia 80, pp. 1-70.

Haggis, D.C., M.S. Mook, R.D. Fitzsimons, C.M. Scarry, and L.M. Snyder. 2011b. "The Excavation of Archaic Houses at Azoria in 2005-2006," Hesperia 80, pp. 431-489.

Hansen, M.H. 1997. "The Polis as an Urban Centre: The Literary and Epigraphical Evidence," in The Polis as an Urban Centre and as a Political Community, Symposium August, 29-31, 1996 (Acts of the Copenhagen Polis Centre 4), M.H. Hansen, ed., Copenhagen, 9-86.

Hansen, M. H., and T. Fischer-Hansen. 1994. "Monumental Political Architecture in Archaic and Classical Greek Poleis: Evidence and Historical Significance," in From Political Architecture to Stephanus Byzantius: Sources for the Ancient Greek Polis (Papers from the Copenhagen Polis Centre 1), D. Whitehead, ed., Stuttgart, pp. 23-90.

Kotsonas, A. 2002. "The Rise of the Polis in Central Crete," Eulimene 3, pp. 37-74.

Kowalewski, S.A. 2006. "Coalescent Societies," in Light on the Path: The Anthropology and History of the Southeastern Indians, T.J. Pluckhahn and R. Ethridge, eds., Tuscaloosa, pp. 94-122.

Miller, S. 1978. The Prytaneion: Its Function and Architectural Form, Berkeley.

Morgan, C., and J. Coulton. 1997. "The Polis as a Physical Entity," in The Polis as an Urban Centre and as a Political Community, Symposium August, 29-31, 1996 (Acts of the Copenhagen Polis Centre 4), M.H. Hansen, ed., Copenhagen, pp. 87-144.

Morris, I. 1991. "The Early Polis as City and State," in City and Country in the Ancient World, J. Rich and A. Wallace-Hadrill, eds., London, pp. 25-57.

Nowicki, K. 2000. Defensible Sites in Crete c.1200-800 B.C. (LM IIIB/IIIC through Early Geometric) (Aegaeum 21), Liège.

Osborne, R. 2005. "Urban Sprawl: What is Urbanization and Why does it Matter?," in Mediterranean Urbanization 800-600 B.C., R. Osborne and B. Cunliffe, eds., Oxford, pp. 1-16.

-. 2009. "Urban Landscape and Architecture," in The Oxford Handbook of Hellenic Studies,

G. Boys-Stones, B. Graziosi, and P. Vasunia, eds., Oxford, pp. 238-247.

Osborne, R., and B. Cunliffe, eds. 2005. Mediterranean Urbanization 800-600 B.C., Oxford. 
Owen, S., and L. Preston, eds. 2009. Inside the City in the Greek World: Studies of Urbanization from the Bronze Age to the Hellenistic Period, Cambridge.

Perlman, P. 2004. "Tinker, Tailor, Soldier, Sailor: The Economies of Archaic Eleutherna, Crete," ClAnt 23, pp. 95-136.

Polignac, F. de. 1995. Cults, Territory, and the Origins of the Greek City-State, Chicago.

-. 2005. "Forms and Processes: Some Thoughts on the Meaning of Urbanization in Early Archaic Greece," in R. Osborne and B. Cunliffe, eds., Mediterranean Urbanization 800-600 B.C., Oxford, pp. 45-70.

Prent, M. 2007. "Cretan Early Iron Age Hearth Temples and the Articulation of Sacred Space," in Building Communities: House, Settlement and Society in the Aegean and Beyond. Proceedings of a Conference held at Cardiff University 17-21 April 2001 (BSA Studies 15), R. Westgate, N. Fisher, and J. Whitley, eds., London, pp. 140-148.

Preston, L., and S. Owen. 2009. "Introduction: Inside the City in the Greek World," in Inside the City in the Greek World: Studies of Urbanization from the Bronze Age to the Hellenistic Period, S. Owen and L. Preston, eds., Cambridge, pp. 1-13.

Raaflaub, K.A. 1993. "Homer to Solon: The Rise of the Polis: The Written Sources," in The Ancient Greek City-State: Symposium on the Occasion of the $250^{\text {th }}$ Anniversary of The Royal Danish Academy of Sciences and Letters, July 1-4, 1992 (Historisk-filosofiske Meddelelser 67), M.H. Hansen, ed., Copenhagen, pp. 41-105.

Sjögren, L. 2008. Fragments of Archaic Crete: Archaeological Studies on Time and Space, Uppsala. Small, D.B. 2010. "The Archaic Polis of Azoria: A Window into Cretan 'Polital' Social Structure," JMA 23, pp. 197-217.

Wallace, S.A. 2010a. "The Roots of the Cretan Polis: Surface Evidence for the History of Large Settlements in Central Crete," AA 2010 (1), pp. 13-89.

-. 2010b. Ancient Crete: From Successful Collapse to Democracy's Alternatives, Twelfth to Fifth Centuries $B C$, Cambridge.

Watrous L. V., and D. Hadzi-Vallianou. 2004. "Creation of a Greek City-State (Late Minoan IIIC Orientalizing)," in The Plain of Phaistos: Cycles of Social Complexity in the Mesara Region in Crete, L.V. Watrous, D. Hadzi-Vallianou, and H. Blitzer, eds., Los Angeles, pp. 339-350.

Whitley, A.J.M. 2009. "Archaeology," in The Oxford Handbook of Hellenic Studies, G. Boys-Stones, B. Graziosi, and P. Vasunia, eds., Oxford, pp. 720-733.

Yoffee, N. 1997. "The Obvious and the Chimerical: City-States in Archaeological Perspective," in The Archaeology of City-States: Cross-Cultural Approaches, D.L. Nichols and T.H. Charlton, eds., Washington, pp. 255-265. 